Michał URBAS

Uniwersytet Szczeciński

\title{
Rozpowszechnianie prasy lokalnej na przykładzie powiatu polickiego w województwie zachodniopomorskim
}

\section{Wstęp}

\begin{abstract}
A rtykuł przedstawia fragmentaryczne wyniki prowadzonych przeze mnie badań prasy lokalnej w województwie zachodniopomorskim. Szczegółowej analizie poddaję w nich tytuły prasy lokalnej ukazujące się w jednostkach terytorialnych na poziomie powiatu, których w zachodniopomorskim jest 18 wraz z 3 miastami na prawach powiatu. Przedstawiane materiały oparte są na obszernych pomiarach jakościowych i ilościowych. Różnorodność prasy lokalnej, jej bogactwo, rozkwit i przemijanie, jest nieodłącznie związana także z przedsiębiorczością lokalną oraz procesem komunikacji w społecznościach lokalnych.

Niniejszy artykuł składa się z trzech części. Pierwsza wyjaśnia terminologię prasy i rynku prasowego. Druga dotyczy charakterystyki społeczności lokalnej powiatu polickiego. Trzecia natomiast omawia wyniki przeprowadzonych badań jakościowych oraz prezentuje analizę ilościową rozpowszechniania tytułów prasy lokalnej.

Różnie dzieli się prasę pod względem obszaru kolportażu. Dlatego wyróżniamy prasę m.in.:

- ogólnokrajową;

- ponadregionalną;

- regionalną;

- lokalną.
\end{abstract}

Powyższy podział nie wyczerpuje możliwości typologizacji prasy pod względem kolportażu. Warto także nadmienić o segmentacji prasy pod względem częstotliwości, tematyki, funkcji wydawniczych, kolportażowych, czytelniczych, przynależności politycznej, techniki druku, etc. ${ }^{1}$

1 R. Kowalczyk, Media lokalne w Polsce, Poznań 2009, s. 29. 
W niniejszym artykule przyjęto kryterium administracyjne wyodrębniania obszaru kolportażu prasy lokalnej oraz ujęcie socjologiczne jej analizy. Kryterium administracyjne wyodrębnia powiat, który obejmuje lokalną wspólnotę samorządową (ogół mieszkańców) oraz odpowiednie terytorium (obejmuje obszar od kilku do kilkunastu gmin albo obszar miasta na prawach powiatu, tj. gminy o statusie miasta, której przyznane zostały prawa powiatu $)^{2}$.

\section{Obszar badań}

Badaniami objęto powiat policki, w którego skład wchodzą gminy: Dobra (Szczecińska), Kołbaskowo, Nowe Warpno - miasto, Nowe Warpno - obszar wiejski, Police - miasto oraz Police - obszar wiejski. Natomiast ujęcie socjologiczne analizy prasy lokalnej odnosi się do takich pojęć, jak społeczeństwo obywatelskie oraz miejskie i wiejskie. Socjologia bowiem, jako nauka badająca m.in. przejawy ludzkiej kultury, zachowań, wzajemnych interakcji oraz przemian społecznych, umożliwia właściwy sposób rozumienia struktur społecznych, w tym społeczności lokalnej. Społeczność lokalna to zbiorowość zamieszkująca wspólny obszar, terytorium, relatywnie samowystarczalna, oparta na trwałym systemie więzi i interakcji społecznych. Charakteryzuje się mocnym poczuciem przynależności jednostek do konkretnej społeczności i stanowi wyraz identyfikacji z nią. Społeczeństwo obywatelskie według Georga Hegla udziela szerokich instytucjonalnych gwarancji dla systemów interpersonalnych lub jak podaje Thomas Hobbes, zakłada ochronę prywatnej własności. Nie sposób nie nadmienić przy tej okazji charakteru społeczeństwa miejskiego i wiejskiego. W skrócie społeczeństwo miejskie to takie, którego członkowie zamieszkują obszar zurbanizowany, miejski, który charakteryzuje się m.in. słabą kontrolą społeczną. Natomiast społeczeństwo wiejskie jest przyporządkowane produkcji rolniczej i charakteryzuje się dosyć wysoką wspólnotowością członków i kontrolą społeczną ${ }^{3}$.

Według danych Głównego Urzędu Statystycznego na koniec września 2009 roku stopa bezrobocia w powiecie polickim wynosiła 16,1\%, a średnia cena dziennika lokalnego kształtowała się na poziomie 1,47 zł. Tabela 1

2 Ustawa z dnia 5 czerwca 1998 r. o samorzqdzie powiatowym (Dz. U. 2001, $\mathrm{Nr}$ 142, poz. 1592 z późn. zm.).

${ }^{3}$ K. Olechnicki, P. Załęcki, Stownik socjologiczny, Toruń 2000, s. 200. 
zawiera dane statystyczne powiatu polickiego według stanu na dzień 30 czerwca 2008 roku.

Tabela 1

Powiat policki w liczbach (stan na 30.06.2008)

\begin{tabular}{|c|c|c|c|c|}
\hline \multicolumn{5}{|c|}{ Powat policki } \\
\hline \multirow{5}{*}{ Liczba mieszkańców } & ogólem & & w tym & \\
\hline & \multirow{4}{*}{67166} & w miastach & 35392 & $52,50 \%$ \\
\hline & & na wsi & 31774 & $47,30 \%$ \\
\hline & & kobiety & 34086 & $51,00 \%$ \\
\hline & & mężczyźni & 33080 & $49,00 \%$ \\
\hline Zaludnienie powiatu & \multicolumn{4}{|c|}{$101,12 \mathrm{mieszk} . / \mathrm{km}^{2}$} \\
\hline Powierzchnia powiatu & \multicolumn{4}{|c|}{$664,16 \mathrm{~km}^{2}$} \\
\hline
\end{tabular}

Źródło: Starostwo powiatowe. Opracowanie własne.

Police (do 1945 roku Pölitz) to miasto powiatowe w województwie zachodniopomorskim, położone nad Odrą. Powiat policki położony jest wzdłuż Zalewu Szczecińskiego i malowniczej Roztoki Odrzańskiej. Władze i mieszkańcy powiatu doceniają bogactwo środowiska naturalnego, nie tylko pod kątem walorów rekreacyjnych, ale przede wszystkim turystycznych. Miasto jest ośrodkiem przemysłu chemicznego z Zakładami Police na czele. Ponadto w Policach znajdują się przedsiębiorstwa przemysłu metalowego, materiałów budowlanych, przemysłu meblowego, odzieżowego i spożywczego. Police posiadają port pełnomorski i rzeczny. Prawa miejskie nadano Policom już w 1260 roku. W latach 30. XX w. w Policach istniał zakład Norddeutsche Mineralölwerke GMBH, regenerujący niezużyte paliwa okrętowe. Na bazie tej firmy w 1938 roku rozpoczęto budowę wielkiej fabryki benzyny syntetycznej. 26 kwietnia 1945 roku 31 dywizja piechoty ze 116 korpusu II armii uderzeniowej Armii Czerwonej wkroczyła do Polic ${ }^{4}$.

Police, gmina Nowe Warpno, Kołbaskowo czy też Dobra Szczecińska nie mają autochtonicznej ludności. Społeczność lokalna jest napływowa w ramach zasiedlania ziem przyłączonych po 1945 roku do Polski.

Kolejnym zagadnieniem wymagającym omówienia są warunki społeczno-gospodarcze występujące w powiecie polickim. W tabelach 2-7 znajdziemy wybrane dane statystyczne charakteryzujące powiat policki ${ }^{5}$.

4 B. Szyszyło, Powiat policki-dzieje Polic po II wojnie światowej, Police 2001.

5 Biuletyn statystyczny województwa zachodniopomorskiego, Szczecin 2009. 
Ruch naturalny ludności w powiecie polickim w I półroczu 2009 roku

\begin{tabular}{||c|c|c|c|c|c|c|c||}
\hline \multicolumn{7}{||c||}{ Ruch naturalny ludności w I półroczu 2009 r. } \\
\hline $\begin{array}{c}\text { małżeń- } \\
\text { stwa }\end{array}$ & urodzenia & $\begin{array}{c}\text { zgony } \\
\text { ogółem }\end{array}$ & $\begin{array}{c}\text { przyrost } \\
\text { naturalny }\end{array}$ & $\begin{array}{c}\text { małżeń- } \\
\text { stwa }\end{array}$ & urodzenia & $\begin{array}{c}\text { zgony } \\
\text { ogólem }\end{array}$ & $\begin{array}{c}\text { przyrost } \\
\text { naturalny }\end{array}$ \\
\hline \multicolumn{7}{|c|}{ na 1000 ludności } \\
\hline 160 & 193 & 228 & 158 & 4,73 & 11,35 & 11,89 & 4,67 \\
\hline
\end{tabular}

Źródło: Urząd Statystyczny w Szczecinie. Opracowanie własne.

Bezrobotni zarejestrowani oraz oferty pracy w powiecie polickim (stan na 09.2009)

\begin{tabular}{||c|c|c|c|c|c|c||}
\hline \multicolumn{7}{|c|}{ Bezrobotni zarejestrowani oraz oferty pracy w 2009 r. } \\
\hline ogólem & kobiety & $\begin{array}{c}\text { bez prawa } \\
\text { do zasilku }\end{array}$ & $\begin{array}{c}\text { dotychczas } \\
\text { niepra- } \\
\text { cujący }\end{array}$ & $\begin{array}{c}\text { w okresie 12 } \\
\text { m-cy od ukoń- } \\
\text { czenia nauki }\end{array}$ & $\begin{array}{c}\text { stopa bezro- } \\
\text { bocia w \% }\end{array}$ & $\begin{array}{c}\text { oferty } \\
\text { pracy }\end{array}$ \\
\hline 3649 & 2059 & 2998 & 1016 & 53 & 16,1 & 59 \\
\hline
\end{tabular}

Źródło: Urząd Statystyczny w Szczecinie. Opracowanie własne.

Tabela 4

Bezrobotni według poziomu wykształcenia w powiecie polickim (stan na 09.2009)

\begin{tabular}{||c|c|c|c|c||}
\hline \hline \multicolumn{5}{|c||}{ Bezrobotni według poziomu wyksztalcenia w 2009 r. } \\
\hline \multirow{2}{*}{ wyższe } & $\begin{array}{c}\text { średnie } \\
\text { zawodowe }\end{array}$ & $\begin{array}{c}\text { średnie } \\
\text { ogólnokształcące }\end{array}$ & $\begin{array}{c}\text { zasadnicze } \\
\text { zawodowe }\end{array}$ & $\begin{array}{c}\text { gimnazjalne } \\
\text { i niższe }\end{array}$ \\
\hline 354 & 692 & 344 & 877 & 1382 \\
\hline
\end{tabular}

Źródło: Urząd Statystyczny w Szczecinie. Opracowanie własne.

Podmioty gospodarki narodowej w powiecie polickim (stan na 09.2009)

\begin{tabular}{|c|c|c|c|c|c|c|}
\hline \multicolumn{7}{|c|}{ Podmioty gospodarki narodowej w 2009r. } \\
\hline \multirow[b]{2}{*}{ ogółem } & \multirow{2}{*}{\begin{tabular}{|c} 
razem \\
osoby prawne \\
i jednostki organiza- \\
cyjne niemające \\
osobowości prawnej
\end{tabular}} & \multicolumn{2}{|c|}{ w tym } & \multicolumn{2}{|c|}{ spólki handlowe } & \multirow[b]{2}{*}{$\begin{array}{l}\text { spółki } \\
\text { cywilne }\end{array}$} \\
\hline & & $\begin{array}{c}\text { przedsię- } \\
\text { biorstwa } \\
\text { państwowe }\end{array}$ & $\begin{array}{l}\text { spółdziel- } \\
\text { nie }\end{array}$ & razem & $\begin{array}{c}\text { z udziałem } \\
\text { kapitału } \\
\text { zagra- } \\
\text { nicznego }\end{array}$ & \\
\hline 8567 & 1625 & - & 29 & 542 & 161 & 538 \\
\hline
\end{tabular}

Źródło: Urząd Statystyczny w Szczecinie. Opracowanie własne. 
Branże dzialalności gospodarczej prowadzonej w powiecie polickim (stan na 09.2009)

\begin{tabular}{|c|c|c|c|c|c|c|c|c|c|c|}
\hline \multicolumn{11}{|c|}{ Osoby prowadzące działalność gospodarczą w 2009 r. } \\
\hline స్ & 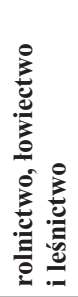 & 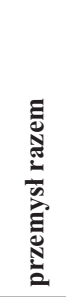 & 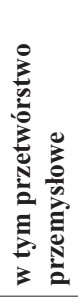 & 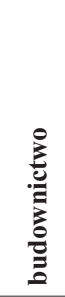 & 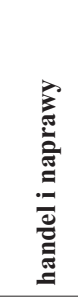 & 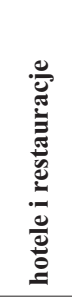 & 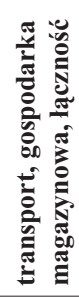 & 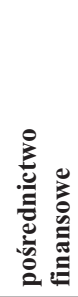 & 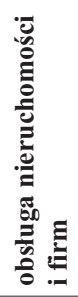 & 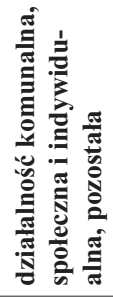 \\
\hline 6942 & 117 & 850 & 847 & 961 & 1801 & 188 & 551 & 286 & 1195 & 305 \\
\hline
\end{tabular}

Źródło: Urząd Statystyczny w Szczecinie. Opracowanie własne.

Przestępczość w powiecie polickim (stan na 09.2009)

\begin{tabular}{|c|c|c|c|c|c|c|}
\hline \multicolumn{7}{|c|}{ Przestępstwa stwierdzone w zakończonych postępowaniach przygotowawczych w $2009 \mathrm{r}$} \\
\hline \multirow{3}{*}{ ogólem } & \multicolumn{3}{|c|}{ w tym } & \multicolumn{3}{|c|}{ z przestępstw ogólem } \\
\hline & \multirow{2}{*}{$\begin{array}{c}\text { o charakte- } \\
\text { rze krymi- } \\
\text { nalnym }\end{array}$} & \multirow{2}{*}{$\begin{array}{c}\text { o charakte- } \\
\text { rze gospo- } \\
\text { darczym }\end{array}$} & \multirow[b]{2}{*}{ drogowe } & \multirow{2}{*}{$\begin{array}{c}\text { przeciwko } \\
\text { życiu } \\
\text { i zdrowiu }\end{array}$} & \multicolumn{2}{|c|}{ przeciwko mieniu } \\
\hline & & & & & razem & $\begin{array}{c}\text { w tym kradzieże } \\
\text { samochodu }\end{array}$ \\
\hline 1307 & 958 & 53 & 248 & 41 & 574 & 9 \\
\hline
\end{tabular}

Źródło: Urząd Statystyczny w Szczecinie. Opracowanie własne.

Jak można wywnioskować z przedstawionych danych, powiat policki charakteryzuje się dużym poziomem bezrobocia, a zatrudnienie skoncentrowane jest wokół Zakładów Chemicznych Police S.A. Dla potrzeb przemysłu i gospodarki, w tym dla potencjalnych inwestorów, przeznaczono 137 hektarów specjalnej strefy ekonomicznej pod nazwą Infrapark.

\section{Rynek prasowy i reklama prasowa}

O ile rynek prasowy w ujęciu ekonomicznym możemy określić jako ogół podmiotów wymiany dóbr i usług niematerialnych, o tyle w ujęciu szczegółowym to zespół warunków ekonomicznych prasy, w tym czyn- 
ników związanych z wydawnictwem, dystrybucją oraz marketingiem ${ }^{6}$. Należy zwrócić uwagę, że rynek prasowy to nie tylko magia nakładów oraz zwrotów czołowych dzienników czy też najpoczytniejszych czasopism, ale to ogół aktorów biorących w nim udział. Kto zatem może zostać uczestnikiem rynku prasowego? Artykuł 8 prawa prasowego stwierdza:

- „wydawcą może być osoba prawna, fizyczna lub inna jednostka organizacyjna, choćby nie posiadała osobowości prawnej. W szczególności wydawcą może być organ państwowy, przedsiębiorstwo państwowe, organizacja polityczna, związek zawodowy, organizacja spółdzielcza, samorządowa i inna organizacja społeczna oraz kościół i inny związek wyznaniowy;

- organizacja polityczna, związek zawodowy, przedsiębiorstwo państwowe, organizacja spółdzielcza, samorządowa i inna organizacja społeczna oraz kościół i inny związek wyznaniowy może realizować uprawnienia wydawnicze bezpośrednio lub za pośrednictwem wydawnictw własnych, jak również innych wydawnictw, działających jako nakładca".

Przywoływane rozwiązania, jak możemy zauważyć, nie są doskonałe. Jednak prawo prasowe wprowadza ład i pewnego rodzaju przewidywalność zachowań poszczególnych uczestników rynku prasowego i mediów. Pomimo, iż zawiera zapisy które wymagają natychmiastowych zmian, jak choćby powoływanie się na Konstytucję Polskiej Rzeczpospolitej Ludowej. Prawo prasowe wymaga dostosowania do realiów obowiązujących dzisiaj na rynku mediów. Zmianie, wydaje się absolutnie koniecznej, należy poddać art. 20 pkt 1 prawa prasowego, który mówi, że „wydawanie dziennika lub czasopisma wymaga rejestracji w sądzie wojewódzkim”. Co oczywiście jest nieprawdą, gdyż takowych sądów od dobrych kilku lat już nie ma, a odpowiednim organem rejestrowym jest Sąd Okręgowy właściwy miejscowo dla siedziby wydawcy.

Należy również pamiętać, iż z rynkiem prasowym nieodłącznie wiąże się reklama prasowa. Prasa umożliwia pogłębienie przekazu reklamowego. Oznacza to, że czytelnik może dowiedzieć się znacznie więcej o produkcie bądź usłudze aniżeli widz z reklamy telewizyjnej czy słuchacz z reklamy radiowej. Badania wskazują, że liczba oglądalności reklamy w prasie jest wielokrotna, a więc czytelnik ma możliwość powracania do treści kilkakrotnie w ciągu tygodnia, miesiąca czy dłuższego okresu. „Aby reklamę zapamiętało 40\% osób mających z nią styczność, potrzeba:

${ }^{6}$ Cz. Bywalec, Gazeta - dobro materialne czy ustuga?, „Zeszyty Prasoznawcze” 1983, nr 1, s. 59. 
3 emisji w TV lub 5 ogłoszeń prasowych, lub 10 emisji w radiu"”. Reklama prasowa posiada walor interaktywności. Oznacza to, że oprócz podstawowych informacji o produkcie dowiemy się z reklamy zarówno o miejscu jego sprzedaży, jak i cenie czy właściwościach. Mało tego, możemy dostać próbkę produktu lub nawet, jak w przypadku programów usługowych - próbkę usługi. Jest to niewątpliwie koronnym atutem prasy. Możliwości umieszczania przekazów reklamowych w prasie jest wiele. Począwszy od insertów, wrzutek różnego rodzaju, wszywek, banderolek, pasków zapachowych, zakładek, płyt, rozkładówek, skrzydełek rozchylanych, artykułów reklamowych kontekstowych, artykułów sponsorowanych, etc. Formy i rodzaje przekazów reklamowych w prasie ograniczone sąjedynie poziomem kreatywności, a możliwości są niemal nieskrępowane.

Niezależnymi pojęciami, które funkcjonują na rynku prasowym, związanymi z reklamą są wskaźniki reklamy ${ }^{8}$. Warto przy tej okazji wspomnieć o kilku podstawowych. Bada się zasięg kampanii, czyli grupę czytelniczą, która zetknie się z reklamą. Analizuje się współczytelnictwo, czyli grupę czytelniczą danego pisma, która jest jednocześnie grupą czytelniczą innego pisma. Sprawdza się zasięg efektywny oraz zasięg wyłączny pisma. Pierwszy termin oznacza, że jest to grupa czytelnicza, do której przekaz reklamowy dotarł na tyle skutecznie, iż został przez czytelników zapamiętany, drugi termin oznacza natomiast odsetek czytelników z grupy docelowej, którzy są tylko i wyłącznie czytelnikami badanego tytułu. Dalej wyróżniamy takie współczynniki, jak: dopasowanie tytułu do docelowej grupy czytelniczej i miarę intensywności oddziaływania kampanii reklamowej. Miara ta nazywana w skrócie GRP obrazuje sumę oglądalności publikacji wszystkich reklam wśród docelowej grupy czytelniczej. Dodatkowo pomiarom podlega odsetek czytelników, do których przekaz reklamowy dotarł jeden raz, dwa, trzy itd., w skrócie $\mathrm{OTS}_{1,2,3}$...n. Częstotliwość, czyli liczba kontaktów z przekazem reklamowym w grupie docelowej czytelników, mierzona jest jako ilość przeciętna oraz efektywna. Wartość częstotliwości efektywnej jest parametrem w gruncie rzeczy czysto teoretycznym, bowiem z góry zakłada się minimalną ilość emisji reklamy, która będzie skuteczna w grupie czytelniczej. Omawiając wskaźniki reklamy prasowej należy przytoczyć także wskaźniki ekonomiczne. Do takowych zaliczyć można:

7 Telewizja Polska S.A. w Szczecinie, http://ww6.tvp.pl/6557,924035,1.view\#4 (2.12.2009).

${ }^{8}$ T. Kowalski, B. Jung, Media na rynku. Wprowadzenie do ekonomiki mediów, WAiP 2008, s. 68. 
- koszt kampanii reklamowej na sprzedany egzemplarz (w skrócie CPI);

- koszt jednego punktu GRP - zasięgu reklamy (w skrócie CPP);

- koszt, jaki ponosi się na dotarcie kampanii reklamowej do 1000 osób z docelowej grupy czytelniczej, która zobaczy przynajmniej jedną emisję reklamy (w skrócie CPT).

\section{Media lokalne w powiecie polickim (dane statystyczne)}

Tabela 8 obejmuje dane na temat zarejestrowanych tytułów prasowych w Sądzie Okręgowym w Szczecinie dla powiatu polickiego do 2008 roku. Dane dotyczące zarejestrowanych tytułów można uzyskać w Rejestrze Dzienników i Czasopism. Rejestr jest jawny i znajduje się w czytelni akt Sądu Okręgowego w Warszawie. Szczegółowe informacje na temat Rejestru Dzienników i Czasopism można odszukać w internetowym wydaniu „Biuletynu Informacji Publicznej” Sądu Okręgowego.

Tabela 8

Pisma zarejestrowane w powiecie polickim w latach 1990-2008

\begin{tabular}{|c|c|c|c|c|c|c|c|c|}
\hline \multirow[b]{2}{*}{ Rok } & \multicolumn{8}{|c|}{ Periodyczność } \\
\hline & $\begin{array}{l}\text { dwumie- } \\
\text { sięcznik }\end{array}$ & $\begin{array}{l}\text { dwuty- } \\
\text { godnik }\end{array}$ & $\begin{array}{c}\text { kwartal- } \\
\text { nik }\end{array}$ & $\begin{array}{c}\text { mie- } \\
\text { sięcznik }\end{array}$ & $\begin{array}{c}\text { półrocz- } \\
\text { nik }\end{array}$ & rocznik & tygodnik & $\begin{array}{c}\text { suma } \\
\text { końcowa }\end{array}$ \\
\hline 1990 & & 1 & & 1 & & & 1 & 3 \\
\hline 1991 & & 2 & & 3 & & & & 5 \\
\hline 1992 & & & & 1 & 6 & & & 7 \\
\hline 1995 & & & & 2 & & & 2 & 4 \\
\hline 1996 & & & & 1 & & & 1 & 2 \\
\hline 1997 & 1 & & & & & & & 1 \\
\hline 1998 & & 1 & & & & & 1 & 2 \\
\hline 1999 & & & & & & & 1 & 1 \\
\hline 2000 & 1 & & & 2 & & & & 3 \\
\hline 2001 & & & & 2 & & & & 2 \\
\hline 2002 & 1 & & & 2 & & 1 & & 4 \\
\hline 2003 & & & 1 & 1 & & & & 2 \\
\hline 2004 & & 1 & 1 & 1 & & & & 3 \\
\hline 2005 & & & 1 & & & & & 1 \\
\hline 2006 & & & 1 & 1 & & & & 2 \\
\hline 2007 & 1 & & & 1 & & & 2 & 4 \\
\hline 2008 & 2 & & 1 & & & & 5 & 8 \\
\hline $\begin{array}{c}\text { Suma } \\
\text { końcowa }\end{array}$ & 6 & 5 & 5 & 18 & 6 & 1 & 13 & 54 \\
\hline
\end{tabular}

Źródło: Sąd Okręgowy w Szczecinie. Opracowanie własne. 
Spośród liczby zgłoszeń rejestracyjnych wyszczególniamy w kolejności: miesięczniki 33,33\%, tygodniki (24,07\%), dwumiesięczniki 11,11\%, półroczniki 11,11\%, dwutygodniki 9,26\%, kwartalniki 9,26\%, roczniki $1,85 \%$. Szczytowy okres rejestracji tytułów prasowych przypada na lata $1992(12,96 \%)$ i $2008(14,81 \%)$.

W 2009 roku ruszyły zakrojone na szeroką skalę prace badawcze nad mediami lokalnymi w województwie zachodniopomorskim, na początek w powiecie polickim. Badania dotyczyły trzech zasadniczych zakresów. Pierwszym było opracowanie ankiety badawczej, określającej profil wydawcy i charakter wydawanego tytułu prasowego. Drugim było badanie dostępnej adresografii. Trzecim natomiast sondowanie danych organu rejestrowego. W ankiecie znalazły się pytania standardowe, takie same dla każdego badanego tytułu prasowego oraz inne dla mediów telewizyjnych i radiowych. Konstrukcja ankiety jest tak zaprojektowana, by była możliwość łatwego jej wypełniania i późniejszego kodowania. Ankietę podzielono na cztery części. Pierwsza dotyczyła danych o tytule prasowym oraz zawierała metryczkę wydawnictwa. Druga część dotyczyła parametrów technicznych tytułu prasowego, w tym formatu, objętości i druku. Trzecia koncentrowała się na zawartości tematycznej i cechach charakteryzujących gatunki dziennikarskie. Czwarta część eksploatowała zagadnienia związane z dystrybucją pisma, a także, co istotne, dotyczyła składu redakcji. Udział w ankiecie był dobrowolny i nie zdarzyło się, by wydawca odmówił spotkania się z ankieterem i udzielenia odpowiedzi na pytania zawarte $\mathrm{w}$ ankiecie.

Z przeprowadzonych badań wynika, że w powiecie polickim na początku 2009 roku rozpoznawalne były następujące media lokalne:

- jedno radio internetowe, które nie posiadało koncesji i zaprzestało działalności;

- dwie stacje telewizji kablowej: a) TV Police; b) TV Vectra. TV Police nadaje dwa programy lokalne: „Info Police” oraz „Teletydzień”. TV Vectra jest tylko przekaźnikiem sygnału radiowo-telewizyjnego do odbiorców telewizji kablowej;

- jedenaście tytułów prasowych, w tym: jeden tytuł prasy katolickiej, jeden prasy reklamowej, dwa prasy ogólnospołecznej, jeden prasy zakładowej oraz jeden prasy samorządowej. Pozostałe 5 tytułów nie ukazuje się;

- trzy tytuły prasy ponadregionalnej: „Kurier Szczeciński”, „Głos Szczeciński” i „Kontakt Szczeciński”;

- jeden tytuł ogólnokrajowy z dodatkiem lokalnym „Gazeta Wyborcza - Szczecin". 


\section{Prasa lokalna w powiecie polickim}

Dla potrzeb niniejszych badań wytypowano sześć tytułów prasowych, ukazujących się w powiecie polickim. Poniżej przedstawiono krótką ich charakterystykę.

1. „Informator Samorządowy”, wydawca: Stowarzyszenie Wspierania Rozwoju Gospodarczego powiatu polickiego. Nakład 18 tys. egz. Pismo bezpłatne, miesięcznik samorządowy, który zasięgiem obejmuje powiat policki.

2. „Magazyn Police S.A.”, wydawca: Zakłady Chemiczne Police S.A. Nakład od 2 do 3 tys. egz., pismo bezpłatne, miesięcznik. Pismo Zakładów Chemicznych Police S.A. Pismo zakładowo-reklamowo-społeczno-lokalne, kierowane głównie na teren gminy Police.

3. „Magazyn Policki”, wydawca: Wydawnictwo REDAKTOR S.C. Danuta Antowska-Kłys, Jan Antoni Kłys. Nakład od 1 do 2 tys. egz., cena 1,8 zł, dwutygodnik. Pismo należące do osób fizycznych, tworzących spółkę cywilną. Treść społeczno-polityczna. Kolportaż na obszarze gminy Police.

4. „Wieści Polickie”, wydawca: Mediatrans Verlag\&Werbung. Nakład od 1 do 2 tys. egz., cena 1 zł, dwutygodnik. Pismo należące do osoby fizycznej. Treść społeczno-polityczna. Kolportaż na obszarze gminy Police.

5. „Nasza Gmina”, wydawca: FHU OPTIMUM Paweł Wierzchowiec. Nakład około 7 tys. egz., bezpłatny miesięcznik. Pismo należące do osoby fizycznej, o charakterze reklamowym, obejmujące zasięgiem powiat policki.

6. „Świadomi Chrystusa”, wydawca: Parafia pod wezwaniem św. Kazimierza w Policach. Nakład około 1000 egz., pismo parafialne, kwartalnik, kierowany do parafian gminy Police'.

Dodatkowo zidentyfikowano pisma nie ukazujące się, o których brak szczegółowych danych:

1) „Szczeciński Punkt Widzenia. Tygodnik Społeczno-Polityczny” (wkładka Policki Punkt Widzenia), wydawca: TH. TARGPED;

2) „Policki Rynek Pracy”, wydawca: Powiatowy Urząd Pracy w Policach;

3) „Zabytki. Zeszyty z Dziejów Polic”, wydawca: Gmina Police, Urząd Miejski w Policach;

9 Dane z badania ankietowego. Opracowanie własne. 
4) „Nowe Police”, wydawca: Komitet Wyborczy Nowej Postawy Obywatelskiej;

5) „Razem dla Polic”, wydawca: Stowarzyszenie RAZEM dla POLIC.

Porównując dane z organu rejestrowego z tym, co znajduje się faktycznie na polickim rynku prasowym, nasuwa się konkluzja, że jest rozbieżność pomiędzy danymi z tych źródeł. Przyczyn jest kilka. Analiza danych metryczkowych ankiet wykazała, że z sześciu pism ukazujących się w powiecie polickim, trzy są zarejestrowane w Sądzie Okręgowym, a trzy nie. Natomiast z pism nieukazujących się, cztery są zarejestrowane w Sądzie Okręgowym, a jeden nie.

Na polickim rynku prasowym możemy wyróżnić trzy podstawowe podmioty, zajmujące się kolportażem prasy: Ruch S.A., Kolporter S.A., Poczta Polska S.A. Występuje także rozpowszechnianie przez wydawców za pośrednictwem własnej sieci dystrybucji prasy. Sieć dystrybucji prasy to przede wszystkim sprzedaż detaliczna w punktach sprzedaży prasy, tzw. „kioskach”, oraz sklepach spożywczych i delikatesach, placówkach Poczty Polskiej oraz wykładanie w miejscach ogólnie dostępnych: urzędach, zakładach użyteczności publicznej, sklepach itp. Pisma można zakupić także w siedzibie wydawcy.

Zinstytucjonalizowani dystrybutorzy prasy pobierają najmniej dwie opłaty od wydawców:

1) opłata za wprowadzenie tytułu do sieci sprzedaży;

2) marża od sprzedanych egzemplarzy.

Dodatkowe opłaty nalicza się od sposobu zwrotów, a więc czy tytuł jest rozliczany protokolarnie - niesprzedane egzemplarze, zwrócone dystrybutorowi z detalicznych punktów sprzedaży, które trafiają na makulaturę, lub fizyczne - to takie, które dystrybutor zwraca wydawcy.

Mali wydawcy prasy lokalnej zwykle w sposób indywidualny kolportują swoje tytuły i może być to sieć dystrybucji zamknięta - określone podmioty gospodarcze, osiedla mieszkaniowe, zespoły szkolne, gminy wyznaniowe, jednostki samorządowe. W Związku Kontroli Dystrybucji Prasy (ZKDP) z powiatu polickiego nie ma żadnego tytułu zgłoszonego do kontroli dystrybucji. Wydaje się, że lokalni wydawcy nie mają takiej potrzeby, by ogłaszać czy też publikować dane o płatnym czy też bezpłatnym rozpowszechnianiu swoich tytułów. Tworzą swój „biznes” w większości jako jednoosobowe podmioty, prowadzące działalność gospodarcza, gdzie sprzedaż detaliczna prasy wiąże się ze sprzedażą reklamy oraz pozyskiwaniem sponsorów lokalnych (głównie poprzez znajomości), tym 
samym uzależniając od nich ukazanie się nowego numeru. Można zatem przyjąć hipotezę, że rynek prasy lokalnej na razie nie cieszy się większym zainteresowaniem wielkich graczy prasowych i reklamodawców. Przyczyn można upatrywać w tym, że jest to rynek mocno rozdrobniony, nieprzewidywalny, a co za tym idzie wymaga wielu nakładów pracy i wysiłku.

Lokalni wydawcy bardzo chętnie rozmawiają o swoich tytułach. Nie owijają nicią tajemniczości aspektów ekonomicznych wydawnictwa. O prasie w powiecie polickim możemy przeczytać m.in. w serwisie „Gazety Lokalne - Stowarzyszenie Gazet Lokalnych i Tygodnik Lokalny”. Znajdziemy tam informacje na temat „Wieści Polickich”" ${ }^{10}$,Wieści Polickie istnieją od 1999 r. Ukazujemy się regularnie co dwa tygodnie w nakładzie 1000 egz., zaspokajając informacyjne potrzeby mieszkańców powiatu polickiego. Jesteśmy gazetą niezależną, poruszamy w niej ważkie tematy społeczne, polityczne i kulturalne. Od wielu lat z dużym powodzeniem współpracujemy z licznymi zakładami pracy i instytucjami. Angażujemy się we wszelkiego rodzaju akcje o charakterze społeczno-kulturalnym, jednocząc potencjał drzemiący w działalności społecznej i artystycznej aktywnych mieszkańców naszego regionu. Obejmujemy patronatem medialnym niemal wszystkie imprezy sportowe, kulturalne i charytatywne". Dodatkowo jest podany kontakt z redakcją i podstawowe dane teleadresowe. W serwisie tym znajdziemy definicję prasy lokalnej oraz parametryzację czytelnictwa lokalnego: „Gazety lokalne są wydawane przez prywatnych wydawców lub spółdzielnie dziennikarskie. Nie mają nic wspólnego z tzw. gazetami samorządowymi dotowanymi przez władze lokalne. Obejmują swoim zasięgiem obszar co najmniej jednej gminy, znacznie częściej powiatu lub kilku powiatów. Czasem są mylone z gazetami regionalnymi, czyli dziennikami ogólnoinformacyjnymi o zasięgu wojewódzkim, tymczasem gazety lokalne są bliżej związane ze swoimi czytelnikami i mają znaczenie opiniotwórcze dla lokalnych społeczności. 85 samodzielnych gazet lokalnych działa jako porozumienie reklamowe «Tygodnik Lokalny». W skład «Tygodnika Lokalnego» wchodzą wyłącznie płatne tytuły ukazujące się nie rzadziej niż raz w tygodniu, których poziom edytorski jest porównywalny z dziennikami ogólnopolskimi. «Tygodnik Lokalny» to łączny nakład 677000 egzemplarzy

${ }^{10}$ Cyt. za: Gazety Lokalne - Stowarzyszenie Gazet Lokalnych i Tygodnik Lokal$n y$, http://www.gazetylokalne.pl/index.php?area $=1 \& \mathrm{p}=$ static\&page=tygodnik-oferta (31.12.2009). 
i dotarcie wykazane w badaniach Millward Brown SMG/KRC do 4 milionów Polaków. «Tygodnik Lokalny» daje pełne pokrycie w 260 powiatach (na 379), czyli jest obecny na terytorium 2/3 Polski - poza miastami wojewódzkimi. W małych miasteczkach i na wsi mieszka 30 milionów Polaków. Są to tak samo atrakcyjni konsumenci, jak mieszkańcy miast wojewódzkich. Poza dużymi miastami czyta się przede wszystkim gazety lokalne. Np. «Tygodnik Siedlecki» na swoim terenie ma czytelnictwo $51 \%$, zaś «Gazetę Wyborczą» - 1\%, a «Fakt»-5\% (według PBC). Dla reklamodawców pieniądze dentysty z Zamościa czy Wrześni mają takie samo znaczenie, jak pieniądze prawnika z Marszałkowskiej w Warszawie. Czytelnicy gazet lokalnych kupująje także ze względu na ogłoszenia”.

W serwisie „Prasa parafialna - serwis o prasie parafialnej dla wydawców i redaktorów prasy parafialnej” znajdziemy informacje o kwartaliku polickim „Świadomi Chrystusa”. Pośród szczegółowych danych teleadresowych wydawcy dostępne są też takie informacje, jak: ,kwartalnik jest to Gazeta Parafii Rzymsko-Katolickiej p.w. Św. Kazimierza w Policach, data powstania pisma: 01-03-1992, redaktor naczelny: ks. dziekan Waldemar Gasztkowski, częstotliwość: kwartalnik, format pisma: A4, nakład pisma: 1500 egz., ISSN: 1505-7585. Informacje dodatkowe od redakcji: pismo ukazywało się jako miesięcznik parafialny do 16 października 2005, potem nastapiła przerwa w wydawaniu, a od kwietnia 2007 zostało wznowione jako kwartalnik dekanalny. Kategoria: pismo dekanalne, status: ukazujące się, sygnatura: 0138 SZ, data dodania do katalogu: 1999"11.

Więcej na temat prasy lokalnej możemy dowiedzieć się w serwisie „Stowarzyszenie Prasy Lokalnej”. Z województwa zachodniopomorskiego znajdziemy tam kilka tytułów prasy lokalnej m.in. „Agrariusz” (miesięcznik) - Szczecin, „Echo Barlinka” (miesięcznik) - Barlinek, „Gazeta Ziemi Pyrzyckiej” (miesięcznik) - Pyrzyce, „Gryfickie Echa” (tygodnik) - Gryfice, „Myśliborskie Wieści” (dwutygodnik) - Myślibórz, „Pyrzyce.info” (portal internetowy) - Pyrzyce, „Tygodnik Ziemi Stargardzkiej” (tygodnik) - Stargard Szczeciński, „Wiadomości Samorządowe” (dwutygodnik) - Nowogard, „Życie Chojnic” (tygodnik) - Chojnice.

Przeprowadzone badania wskazują, że wśród wydawców lokalnych wysoko jest rozwinięta znajomość typologii pisma oraz pojęć edytorsko-wydawniczych. W badaniach nie brano pod uwage profilu czytelnika

11 Prasa parafialna-serwis o prasie parafialnej dla wydawców i redaktorów prasy parafialnej, red. J. Jakubowska, http://prasaparafialna.pl/ (16.12.2009). 
prasy lokalnej w powiecie polickim. Nie badano zatem takich zmiennych dotyczących czytelnika, jak: płeć, wiek, wykształcenie, grupa społeczno-zawodowa, wielkość miasta, wsi, dostęp do Internetu, liczba osób w gospodarstwie domowym czy też dochód, jaki osiaga gospodarstwo domowe.

Wiodącym formatem wydawniczym jest format $297 \times 210 \mathrm{~mm}$ (lub do niego zbliżony) - pięć tytułów. Jedynie „Informator Samorządowy” powiatu polickiego jest wydawany w formacie 280x405 mm. Prasa lokalna jest drukowana głównie ma papierze offsetowym (dwa tytuły), kredowym (trzy tytuły) i gazetowym (jeden tytuł). Badane tytuły ukazujące się w powiecie polickim drukowano w pełnym kolorze lub monokolorze.

Różnorodność istnieje w objętości prasy. Powyżej dwóch arkuszy drukarskich mają trzy tytuły, dwa tytuły mają objętość jednego arkusza drukarskiego, jeden tytuł ma objętość dwóch do trzech arkuszy drukarskich.

Wysokością nakładu króluje „Informator Samorządowy” (18 tys. egz.). Dalej mamy pismo reklamowe $\mathrm{z}$ nakładem około 7 tys. egz., następnie cztery tytuły z nakładem od 1 do 4 tys. egz. To tyle w kwestiach technicznych związanych z wydawaniem prasy lokalnej. Przejdźmy zatem to analizy zawartości pism powiatu polickiego.

Tematyka prasy lokalnej, która zawiera więcej niż 1/4 kolumny, jest lokalna i samorządowa. Tak jest w pięciu na sześć tytułów. Oczywiście analiza zawartości dziennikarskiej nie dotyczy tytułu reklamowego. Wśród wypowiedzi dziennikarskiej dominuje informacja, informacja poszerzona, wywiad, artykuł, recenzja. Co ciekawe, marginalną sprawą są listy od czytelników. Praktycznie w ogóle nie występują one w badanej prasie lokalnej. Cechami charakterystycznymi dla zawartości prasy lokalnej w powiecie polickim jest w większości to, że zawartość jest uporządkowana tematycznie, a zdjęcia ilustrują teksty. Taka sytuacja ma miejsce w pięciu na sześć tytułów.

Interesująca jest sytuacja dotycząca ogłoszeń płatnych. W dwóch tytułach powierzchnia ogłoszeń płatnych zajmuje około jednej kolumny, w jednym zajmuje więcej niż jedną kolumnę, w jednym zajmuje 100\% w szacunkowym udziale całościowym powierzchni pisma, a w dwóch od $20 \%$ do $30 \%$.

Ostatnim elementem analizy prasy lokalnej jest jej skład redakcyjny. Otóż pięć pism ma tylko redaktorów naczelnych, a trzy mają także zastępców redaktorów naczelnych. Jedno pismo ma sekretarza redakcji. Jedno pismo ma czterech stałych pracowników redakcji, a jedno dwóch. Trzy pisma mają odpowiednio pięciu, dwóch i pięciu współpracowników redakcji. Natomiast żadne nie ma wśród swoich pracowników osoby z wykształce- 
niem dziennikarskim. Jedynie jeden tytuł ma jednego współpracownika, który posiada wykształcenie dziennikarskie.

\section{Dystrybucja prasy lokalnej w powiecie polickim}

Przejdźmy do analizy dystrybucji prasy lokalnej. Prasa lokalna w powiecie polickim to $\mathrm{w}$ zdecydowanej większości pisma bezpłatne.

- „Informator Samorządowy”, nakład 18 tys. egz., pismo bezpłatne, rozpowszechnianie ok. 15 tys. egz;

- „Magazyn Police S.A.”, wydawca: Zakłady Chemiczne Police S.A. Nakład od 2,1 do 3 tys. egz., pismo bezpłatne, rozpowszechnianie ok. 2,5 tys. egz.;

- „Magazyn Policki”, nakład od 1 do 2 tys. egz., cena 1,8 zł, rozpowszechnianie płatne od 0,5 do 1 tys. egz., rozpowszechnianie bezpłatne 0,2-0,3 tys. egz.;

- „Wieści Polickie”, nakład od 1 do 2 tys. egz., cena 1 zł, rozpowszechnianie płatne od 0,5 do 1 tys. egz.;

- „Nasza Gmina”, nakład ok. 7 tys. egz., pismo bezpłatne, rozpowszechnianie 7 tys. egz.;

- „Świadomi Chrystusa”, nakład ok. 1 tys. egz., pismo parafialne, kwartalnik.

Kolejnym etapem badań jest syntetyczne przedstawienie rynku prasowego w powiecie polickim w ujęciu danych, jakie udało się zgromadzić. Dane obejmują ${ }^{12}$ :

- liczbę wydań - liczba wydań w danym okresie;

- nakład - liczba egzemplarzowa wydań;

- średni nakład jednorazowy - suma wydań w danym okresie podzielona przez liczbę wydań z tego okresu;

- zwroty - egzemplarze niesprzedane i zwrócone;

- średni zwrot jednorazowy - suma zwrotu w danym okresie podzielona przez liczbę wydań z tego okresu;

- sprzedaż egzemplarzowa - egzemplarze sprzedane;

- średnia sprzedaż jednorazowa - suma sprzedaży w danym okresie podzielona przez liczbę wydań z tego okresu;

- prenumerata - egzemplarze sprzedane na podstawie zamówienia odbiorcy.

12 Definicje zgodne z Regulaminem kontroli ZKDP, Warszawa I.2008. 
Analizując rynek prasowy nie możemy zapomnieć o badaniach czytelnictwa prasy. Czytelnictwo prasy charakteryzuje się m.in. ${ }^{13}$ :

- wskaźnikiem przeciętnej liczby czytelników jednego egzemplarza tytułu prasowego (RPC);

- wskaźnikiem przeciętnej liczby godzin, jaką czytelnik przeznacza na czytanie jednego wydania tytułu prasowego (TSR);

- wskaźnikiem przeciętnej liczby lat, jaka upłynęła od kontaktu czytelnika z tytułem prasowym (YFC);

- wskaźnik przeciętnej wielkości rozpowszechniania jednego wydania tytułu prasowego (CIRC);

- wskaźnik przeciętnego czytelnictwa jednego wydania tytułu prasowego (AIR);

- wskaźnik liczby czytanych wydań tytułu prasowego, np. z czterech (LCW4);

- wskaźnik średniej liczby czytanych wydań tytułu prasowego, np. z czterech (SLCW4);

- wskaźnik przeciętnego czytelnictwa wydania tytułu prasowego, np. z czterech (CPW);

- wskaźnik czytelnictwa cyklu sezonowego tytułu prasowego (CCS);

- wskaźnik czytelnictwa okresu periodyczności tytułu prasowego (COP);

- wskaźnik statystycznego czytelnictwa przeciętnego wydania tytułu prasowego (SCPW);

- wskaźnik dla dzienników - czytelnictwo wydania z dni tygodnia (CDT).

W tabeli 9 przedstawiono przykładową analizę czytelnictwa prasy z badania zrealizowanego przez MillwardBrown SMG/KRC na zlecenie Polskiego Badania Czytelnictwa. Badanie, jak podaje miesięcznik „Press”, „opierało się na wywiadzie przeprowadzanym przez ankietera w domach respondentów ${ }^{14}$. Próba wynosiła 1093 respondentów, co odpowiada 1347246 mieszkańcom. Badanie opierało się na metodzie cyklu sezonowego, tzn. jaki procent osób czytało lub przeglądało najmniej raz w okresie: ostatniego tygodnia - dziennik, ostatniego miesiąca - dwutygodnik, trzech miesięcy - dwutygodnik oraz sześciu miesięcy - miesięcznik"15.

13 Więcej informacji na temat czytelnictwa prasy można znaleźć w serwisach firm: Niezależne Badania Czytelnictwa Prasy (NBCP) oraz Polskie Badania Czytelnictwa (PBC).

$14 \mathrm{~W}$ badaniach PBC prezentowane są wyłącznie dane dla tytułów wydawców będących członkami Polskich Badań Czytelnictwa oraz ZKDP.

15 „Press” 2009, nr 11, s. 82. 
Tabela 9

Badanie czytelnictwa prasy CCS w zachodniopomorskim - dane skumulowane za okres 03-08.2009

\begin{tabular}{||l|c|}
\hline \multicolumn{2}{|c|}{ Zachodniopomorskie } \\
\hline „,Głos - Dziennik Pomorza” & 25,28 \\
\hline „,Kurier Szczeciński” & 19,58 \\
\hline „,Fakt” & 14,22 \\
\hline „Gazeta Wyborcza” & 11,08 \\
\hline „Metro” (dziennik bezpłatny) & 8,06 \\
\hline „Przegląd Sportowy” & 6,75 \\
\hline „,Rzeczpospolita” & 4,43 \\
\hline „Dziennik” & 3,16 \\
\hline „Gazeta Prawna”, Gazeta Lubuska” & 2,40 \\
\hline „Puls Biznesu” & 2,29 \\
\hline „Gazeta Podatkowa” & 0,72 \\
\hline „Echo Miasta” (dziennik bezpłatny) & 0,40 \\
\hline \hline
\end{tabular}

Źródło: „Press” 2009, nr 11. Opracowanie własne.

Najchętniej czytanym dziennikiem w zachodniopomorskim jest „Głos - Dziennik Pomorza", nieco dalszym źródłem informacji dla mieszkańców jest „Kurier Szczeciński”. Powyższe dane potwierdzają również Polskie Badania Czytelnictwa Prasy (PBCP), gdzie „Głos - Dziennik Pomorza” zajmuje pierwsze miejsce $(25,62)$, drugie „Kurier Szczeciński” $(16,85)^{16}$. Wyraźnie widać zainteresowanie czytelników prasą regionalna, ale dostrzegalne jest też zainteresowanie gazetą codzienną „Fakt”, który w rankingu czytelnictwa, tak miesięcznika „Press”, jak i PBCP, niewiele odstaje od „Kuriera Szczecińskiego”, zajmując trzecie miejsce (14,22 i 15,66). Dane obejmujące „Gazetę Lubuską” oraz „Echo Miasta” odzwierciedlają oddziaływanie przygraniczne tych dzienników na czytelników województwa zachodniopomorskiego („Gazeta Lubuska” - ukazuje się na terenie województwa lubuskiego, natomiast „Echo Miasta” - w obszarze Trójmiasta - województwo pomorskie).

16 Wyniki Badania PBC za okres maj-październik 2009 r. wskaźnik CCS (Czytelnictwo Cyklu Sezonowego), rankingi czytelnictwa, populacja (Polacy w wieku 15-75) 30.136.052, http://www.pbczyt.pl/page.php?d=2\&p=6\&m=4\&c=1\&w=17 (17.12.2009). 
Firm i instytucji, które zajmują się badaniem czytelnictwa jest w Polsce dużo, a prezentowane wyniki często pozostawiają wiele do życzenia lub są po prostu rozbieżne. Dodatkowo badanie czytelnictwa prasy jest łączone lub bywa wiązane z rozpowszechnianiem. Dane, którymi posiłkują się firmy, zajmujące się badaniem czytelnictwa, pobierane są w chwili obecnej z ZKDP. Przeanalizowanie czytelnictwa prasy lokalnej w obecnym zakresie jest więc mocno utrudnione lub wręcz niemożliwe. O tym jak wygląda badanie czytelnictwa prasy, a jaka jest rzeczywistość, pisał już w 1997 roku Henryk Siwek na łamach „Zeszytów Prasoznawczych" ${ }^{\text {"17 }}$. Wydaje się, że w dużej mierze podnoszone tam zastrzeżenia niewiele straciły na aktualności. Analiza danych obejmująca rynek prasowy w zachodniopomorskim napotyka szereg barier i trudności. Tak często przywoływany Związek Kontroli Dystrybucji Prasy w gruncie rzeczy z tytułów regionalnych ukazujących się na obszarze powiatu polickiego ma w swoich zbiorach tylko dane dla „Kuriera Szczecińskiego” i „Głosu - Dziennika Pomorza”. Poniżej zestawienie danych dla „Kuriera Szczecińskiego” za okres X 2008-X 2009.

Tabela 10

„Kurier Szczeciński”. Dane ZKDP za okres październik 2008-październik 2009

\begin{tabular}{|c|c|c|c|c|c|}
\hline Tytul & Okres & $\begin{array}{l}\text { Liczba } \\
\text { wydań }\end{array}$ & $\begin{array}{c}\text { Średni nakład } \\
\text { jednorazowy }\end{array}$ & $\begin{array}{l}\text { Sprzedaż } \\
\text { ogółem }\end{array}$ & Zwroty \\
\hline \multirow{13}{*}{$\begin{array}{l}\text { „Kurier } \\
\text { Szczeciński” }\end{array}$} & październik 2008 & 23 & 35498 & 24197 & 10331 \\
\hline & listopad 2008 & 19 & 35053 & 24385 & 9718 \\
\hline & grudzień 2008 & 21 & 33692 & 22993 & 9843 \\
\hline & styczeń 2009 & 21 & 36590 & 24972 & 10663 \\
\hline & luty 2009 & 20 & 34281 & 23210 & 10127 \\
\hline & marzec 2009 & 22 & 33494 & 22671 & 9934 \\
\hline & kwiecień 2009 & 21 & 37995 & 25455 & 11582 \\
\hline & maj 2009 & 20 & 35359 & 23532 & 10808 \\
\hline & czerwiec 2009 & 21 & 34518 & 22519 & 10883 \\
\hline & lipiec 2009 & 23 & 33422 & 22389 & 9838 \\
\hline & sierpień 2009 & 21 & 31088 & 21508 & 8191 \\
\hline & wrzesień 2009 & 22 & 30325 & 21155 & 7727 \\
\hline & październik 2009 & 22 & 32723 & 22596 & 8748 \\
\hline
\end{tabular}

Źródło: Związek Kontroli Dystrybucji Prasy. Opracowanie własne.

17 H. Siwek, Badania czytelnictwa prasy. Deklaracje a rzeczywistość, „Zeszyty Prasoznawcze" 1997, nr 3-4, s. 1. 
Zadeklarowana przez wydawcę suma rocznej średniej sprzedaży jednorazowej „Kuriera Szczecińskiego” wyniosła 301582 egz. (67,92\%), średnich zwrotów jednorazowych 128393 egz. (28,91\%), średniego nakładu jednorazowego 444038 egz. przy 276 wydaniach. Miesięczne wartości średnie dla „Kuriera Szczecińskiego” wyniosły odpowiednio: średnia jednorazowa sprzedaż 23199 egz., średnie zwroty jednorazowe 9876 egz., średni nakład jednorazowy 34157 egz. przy 21 wydaniach.

W analogicznym okresie oraz przy wyborze tych samych parametrów z bazy danych ZKDP wygenerowano informacje dla „Głosu - Dziennika Pomorza” (dawniej trzy odrębne tytuły: „Głos Szczeciński”, „Głos Koszaliński” i „Głos Pomorza” w Słupsku). W tabeli 11 dane o rozpowszechnianiu „Głosu - Dziennika Pomorza” również za okres październik 2008-październik 2009.

Tabela 11

„Głos - Dziennik Pomorza”. Dane ZKDP za okres październik 2008-październik 2009

\begin{tabular}{|c|c|c|c|c|c|}
\hline Tytul & Okres & $\begin{array}{l}\text { Liczba } \\
\text { wydań }\end{array}$ & $\begin{array}{c}\text { Średni nakład } \\
\text { jednorazowy }\end{array}$ & $\begin{array}{l}\text { Sprzedaż } \\
\text { ogólem }\end{array}$ & Zwroty \\
\hline \multirow{13}{*}{$\begin{array}{l}\text { "Glos } \\
\text { - Dziennik } \\
\text { Pomorza" }\end{array}$} & październik 2008 & 27 & 57502 & 44307 & 12066 \\
\hline & listopad 2008 & 23 & 58121 & 42488 & 14046 \\
\hline & grudzień 2008 & 25 & 64094 & 46277 & 16951 \\
\hline & styczeń 2009 & 26 & 62632 & 46759 & 14826 \\
\hline & luty 2009 & 24 & 59647 & 45459 & 13126 \\
\hline & marzec 2009 & 26 & 57396 & 44947 & 11065 \\
\hline & kwiecień 2009 & 25 & 58161 & 44275 & 12825 \\
\hline & maj 2009 & 25 & 53949 & 40960 & 11794 \\
\hline & czerwiec 2009 & 25 & 54309 & 44837 & 8513 \\
\hline & lipiec 2009 & 27 & 53959 & 41376 & 11737 \\
\hline & sierpień 2009 & 25 & 52483 & 41340 & 10516 \\
\hline & wrzesień 2009 & 26 & 52229 & 39987 & 11188 \\
\hline & październik 2009 & 27 & 53194 & 40635 & 11619 \\
\hline
\end{tabular}

Źródło: Związek Kontroli Dystrybucji Prasy. Opracowanie własne.

Z powyższych danych wynika, że suma rocznej średniej sprzedaży jednorazowej dla „Głosu - Dziennika Pomorza” wyniosła 563647 egz. (76,41\%), średnich zwrotów jednorazowych 160272 egz. (21,73\%), średniego nakładu jednorazowego 737676 egz., przy 331 wydaniach. Porów- 
nanie w stosunku rocznym danych „Głosu - Dziennika Pomorza” z danymi „Kuriera Szczecińskiego” wykazało, że średnia sprzedaż jednorazowa „Głosu - Dziennika Pomorza” jest większa o 86,90\%, średnie zwroty jednorazowe są większe o $24,83 \%$, średni nakład jednorazowy o $66,13 \%$, a liczba wydań o 19,93\% od „Kuriera Szczecińskiego”. W przedziale miesięcznym wartości średnie dla „Głosu - Dziennika Pomorza” wynoszą: średnia sprzedaż jednorazowa 43357 egz., średnie zwroty jednorazowe 12329 egz., średni nakład jednorazowy wynosił 56744 egz., przy 25 wydaniach.

Oczywiście można przyjąć, że tytuły zgłoszone do kontroli dystrybucji w ZKDP mają znaczący wpływ i kształtują rynek masowego odbiorcy, ale można zaryzykować też twierdzenie, że na pewno nie odzwierciedlają całego rynku prasowego oraz nie pokazują kulturowej i społecznej różnorodności, jaka się wiąże z prasą lokalną.

Prowadząc badania terenowe i korzystając z uprzejmości jednego $\mathrm{z}$ dystrybutorów prasy poniżej przedstawiam syntetyczne zestawienie rozpowszechniania płatnego prasy na terenie powiatu polickiego. $\mathrm{Z}$ danych, które zostały zgromadzone wyodrębniono następujące części składowe podziału terytorialnego:

- Dobra (Szczecińska);

- Kołbaskowo;

- Nowe Warpno - miasto;

- Nowe Warpno - obszar wiejski;

- Police - miasto;

- Police - obszar wiejski;

oraz podziału według periodyczności:

- czasopismo ukazujące się 2 razy w miesiącu;

- czasopismo ukazujące się 3 razy w miesiącu;

- dwutygodnik;

- dziennik ukazujący się 2 razy w tygodniu;

- dziennik ukazujący się 3 razy w tygodniu;

- dziennik ukazujący się 7 razy w tygodniu;

- miesięcznik;

- trzytygodnik;

- tygodnik.

Informacje zawarte w poniższych tabelach obejmują rok kalendarzowy, począwszy od października 2008 roku do października 2009 roku.

Tabela 12 zestawia sumę wydań tytułów prasowych skierowanych do dystrybucji. 


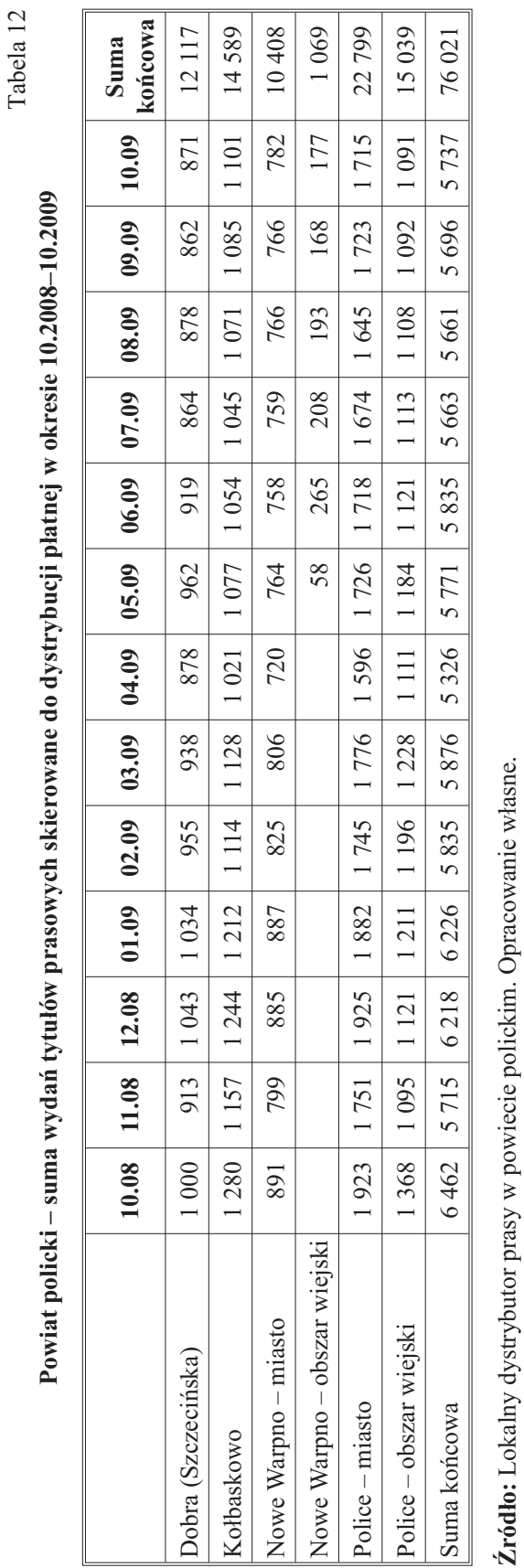


Spośród całości wydań tytułów prasowych skierowanych do dystrybucji płatnej powiatu polickiego, do poszczególnych gmin trafiło: Police - miasto 30\%, Police - obszar wiejski 20\%, Kołbaskowo 19\%, Dobra $16 \%$, Nowe Warpno - miasto 14\% i Nowe Warpno - obszar wiejski 1\%.

Tabela 13 zawiera wysokość nakładów egzemplarzowych tytułów prasowych skierowanych do dystrybucji.

Większość nakładu prasy skierowana została na teren Police - miasto 7,24\% oraz gminy Kołbaskowo 14,60\%, w dalszej kolejności na teren Police - obszar wiejski 12,78\%, gminy Dobra $12,33 \%$, gminy Nowe Warpno - miasto 2,84\%. Najmniejsza część nakładu prasy trafiła do gminy Nowe Warpno - obszar wiejski $0,21 \%$.

Zestawienie zwrotów prasy z dystrybucji płatnej ujęte jest w tabeli 14.

Zdecydowanie najwięcej egzemplarzy niesprzedanej prasy wraca z gminy Police - miasto 59,86\%, gminy Kołbaskowo 13,19\%, Police - obszar wiejski 12,08\%, gminy Dobra 11,80\%. Najmniej wraca prasy z gminy Nowe Warpno - miasto 2,75\% i Nowe Warpno - obszar wiejski $0,32 \%$.

Syntetycznie sprzedaż egzemplarzową prasy skierowanej do dystrybucji zaprezentowano $\mathrm{w}$ tabeli 15 .

Wysoki poziom sprzedaży egzemplarzowej prasy odnotowano w gminach: Police - miasto 55,28\%, Kołbaskowo 15,65\%, Police - obszar wiejski $13,29 \%$ oraz Dobra $12,73 \%$. Najmniejszy poziom sprzedaży egzemplarzowej prasy w gminie Nowe Warpno - miasto 2,91\% i Nowe Warpno - obszar wiejski $0,13 \%$.

W dalszej części zaprezentowane są wyliczenia wartościowe polickiego rynku prasowego. W tabeli 16 przedstawiono wartość (w PLN) nakładów tytułów prasowych.

Wartość nakładów prasy w poszczególnych gminach kształtuje się następująco: Police - miasto $61,76 \%$, Kołbaskowo $13,43 \%$, Police - obszar wiejski 11,31\%, gmina Dobra 10,37\%, Nowe Warpno - miasto 2,99\% i Nowe Warpno - obszar wiejski $0,15 \%$.

Tabela 17 zawiera wartość zwrotów (w PLN) tytułów prasowych.

Wartości zwrotów prasy niesprzedanej: Police - miasto 64,76\%, gmina Kołbaskowo 11,43\%, Police - obszar wiejski 11,12\%, gmina Dobra 9,70\%, Nowe Warpno - miasto 2,80\% i Nowe Warpno - obszar wiejski $0,18 \%$.

Podsumowanie wartości nakładów prasy oraz jej zwrotów znajduje się w tabeli 18, w której znajdziemy wartość sprzedaży (w PLN) poszczególnych tytułów prasowych. 
$\frac{\frac{\pi}{2}}{\frac{\pi}{8}}$

\begin{tabular}{|c|c|c|c|c|c|c|c|}
\hline 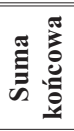 & 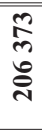 & 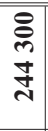 & $\begin{array}{l} \\
0 \\
0 \\
0 \\
7\end{array}$ & $\begin{array}{l}\hat{N} \\
\text { ñ }\end{array}$ & $\begin{array}{l}\infty \\
\infty \\
\infty \\
n\end{array}$ & $\begin{array}{l}\stackrel{N}{2} \\
\stackrel{2}{N}\end{array}$ & 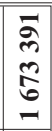 \\
\hline $\begin{array}{l}\stackrel{g}{\theta} \\
\stackrel{\theta}{\theta}\end{array}$ & $\begin{array}{l}\hat{n} \\
\tilde{0}\end{array}$ & $\begin{array}{l}\stackrel{\infty}{\infty} \\
\stackrel{\sim}{\sim}\end{array}$ & $\begin{array}{l}\stackrel{0}{\infty} \\
\stackrel{0}{m}\end{array}$ & $\underset{\infty}{+}$ & \begin{tabular}{l}
\multirow{J}{0}{} \\
\multirow{2}{*}{}
\end{tabular} & $\begin{array}{l}\hat{0} \\
\stackrel{n}{n}\end{array}$ & $\begin{array}{l}\text { ले } \\
\text { மீ }\end{array}$ \\
\hline $\begin{array}{l}\stackrel{g}{\partial} \\
\stackrel{\theta}{\theta}\end{array}$ & $\begin{array}{l}\infty \\
\stackrel{+}{n} \\
\end{array}$ & $\begin{array}{c}\begin{array}{c}\alpha \\
0 \\
\tilde{N}\end{array} \\
\end{array}$ & $\begin{array}{l}\forall \\
\forall \\
m\end{array}$ & $\stackrel{\infty}{8}$ & $\begin{array}{l}\underset{8}{J} \\
\mathbb{N}\end{array}$ & $\begin{array}{l}\infty \\
\stackrel{0}{0} \\
=\end{array}$ & 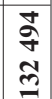 \\
\hline $\begin{array}{l}\stackrel{\partial}{\circ} \\
\text { d. }\end{array}$ & $\begin{array}{l}\text { すి } \\
\underline{0}\end{array}$ & $\begin{array}{l}m \\
\vec{\gamma} \\
\stackrel{\sim}{\sim}\end{array}$ & $\begin{array}{l}\vec{n} \\
\text { m }\end{array}$ & $\overline{6}$ & $\begin{array}{l}\infty \\
\frac{\infty}{6} \\
8\end{array}$ & $\begin{array}{l}\text { N } \\
\text { I }\end{array}$ & $\begin{array}{l}\mathbf{T} \\
\infty \\
\infty \\
\end{array}$ \\
\hline$\frac{\stackrel{\partial}{\circ}}{\hat{\theta}}$ & $\begin{array}{l}\text { ○ } \\
\text { ర } \\
\text { ป }\end{array}$ & 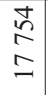 & $\begin{array}{l}m \\
\tilde{O} \\
m\end{array}$ & $\begin{array}{l}n \\
\infty \\
\infty\end{array}$ & 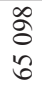 & $\begin{array}{l}n \\
\infty \\
\infty \\
n \\
n\end{array}$ & $\begin{array}{l}\overrightarrow{7} \\
\stackrel{5}{\Xi}\end{array}$ \\
\hline $\begin{array}{l}\stackrel{8}{\partial} \\
\text { ठ }\end{array}$ & 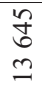 & $\begin{array}{l}\hat{a} \\
\therefore \\
=\end{array}$ & $\begin{array}{l}\vec{\infty} \\
m \\
m\end{array}$ & $\stackrel{2}{2}$ & $\begin{array}{l}\stackrel{n}{N} \\
\hat{\sigma}\end{array}$ & \begin{tabular}{l}
$\infty$ \\
\multirow{2}{0}{} \\
0 \\
0
\end{tabular} & $\begin{array}{l}\mathscr{6} \\
\infty \\
0 \\
=\end{array}$ \\
\hline $\begin{array}{l}\stackrel{\partial}{\partial} \\
\text { है }\end{array}$ & $\begin{array}{l}\hat{\sim} \\
\sim \\
\sim\end{array}$ & $\begin{array}{l}\stackrel{\infty}{\sim} \\
\stackrel{\infty}{二}\end{array}$ & $\begin{array}{l}m \\
\text { m } \\
m\end{array}$ & $\underset{\text { ป }}{ }$ & $\begin{array}{l}\tilde{\sigma} \\
\frac{\sigma}{\sigma}\end{array}$ & $\begin{array}{l}\hat{b} \\
+ \\
0\end{array}$ & $\begin{array}{l}\tilde{\infty} \\
\sigma \\
\Xi\end{array}$ \\
\hline $\begin{array}{l}\stackrel{g}{\ominus} \\
\dot{\sigma}\end{array}$ & $\frac{\infty}{n}$ & $\begin{array}{l}\stackrel{2}{\circ} \\
\therefore \\
\therefore\end{array}$ & $\frac{ \pm}{m}$ & & $\begin{array}{l}\stackrel{2}{R} \\
\text { J্ }\end{array}$ & $\begin{array}{l}\text { aे } \\
\text { ñ }\end{array}$ & $\begin{array}{l}\stackrel{\Xi}{\Xi} \\
\stackrel{\Xi}{\Xi}\end{array}$ \\
\hline $\begin{array}{l}\stackrel{8}{8} \\
\text { ले }\end{array}$ & 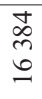 & $\begin{array}{l}\stackrel{8}{ } \\
\infty \\
\infty \\
-\end{array}$ & $\begin{array}{l}\vec{a} \\
m\end{array}$ & & 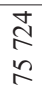 & $\underset{\infty}{\stackrel{\Xi}{\sim}}$ & $\begin{array}{l}\tilde{\Xi} \\
\tilde{\Xi}\end{array}$ \\
\hline $\begin{array}{l}\stackrel{\partial}{\partial} \\
\text { తి }\end{array}$ & $\begin{array}{l}\stackrel{\nabla}{\Delta} \\
\stackrel{n}{n}\end{array}$ & $\begin{array}{l}\hat{0} \\
\underline{=}\end{array}$ & $\begin{array}{l}\hat{\sigma} \\
m \\
m\end{array}$ & & $\begin{array}{l}\sqrt[2]{0} \\
\stackrel{2}{2}\end{array}$ & $\begin{array}{l}\stackrel{0}{N} \\
\stackrel{n}{n}\end{array}$ & 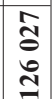 \\
\hline$\frac{\stackrel{8}{\circ}}{\dot{\theta}}$ & 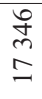 & 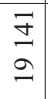 & $\begin{array}{l}\stackrel{2}{\hat{\sigma}} \\
\text { m }\end{array}$ & & $\begin{array}{l}\underset{\mathcal{J}}{\mathrm{O}} \\
\underset{\infty}{ }\end{array}$ & $\begin{array}{l}\hat{n} \\
\approx\end{array}$ & $\begin{array}{l}\mathbb{N} \\
\infty \\
\infty \\
\end{array}$ \\
\hline 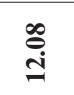 & $\begin{array}{l}8 \\
\infty \\
\infty\end{array}$ & $\begin{array}{l}\stackrel{\text { ते }}{2} \\
\stackrel{2}{二}\end{array}$ & $\begin{array}{l}\mathcal{J} \\
\infty \\
m\end{array}$ & & $\begin{array}{l}n \\
\infty \\
\sim \\
\infty\end{array}$ & $\begin{array}{l}\overline{6} \\
\stackrel{2}{2}\end{array}$ & $\begin{array}{l}\stackrel{?}{1} \\
0 \\
\infty \\
\end{array}$ \\
\hline$\stackrel{\infty}{\stackrel{\infty}{\ominus}}$ & $\frac{N}{n}$ & $\begin{array}{l}0 \\
\check{f} \\
\infty \\
-\end{array}$ & $\begin{array}{l}\vec{n} \\
n \\
m\end{array}$ & & $\begin{array}{l}\stackrel{m}{\sim} \\
\stackrel{\nabla}{\sim}\end{array}$ & $\begin{array}{l}\overline{5} \\
\stackrel{2}{\simeq}\end{array}$ & 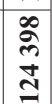 \\
\hline$\stackrel{\infty}{\stackrel{\infty}{\circ}}$ & \begin{tabular}{l}
$\infty$ \\
\multirow{2}{*}{} \\
$\underline{0}$
\end{tabular} & $\begin{array}{l}\infty \\
0 \\
\tilde{N} \\
\bar{\sim}\end{array}$ & $\begin{array}{l}\mathrm{T} \\
\text { a } \\
\text { m }\end{array}$ & & $\begin{array}{l}n \\
\approx \\
0 \\
\infty\end{array}$ & $\begin{array}{l}\text { సे } \\
\infty \\
\text { a }\end{array}$ & 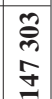 \\
\hline & 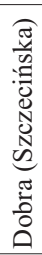 & 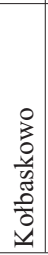 & 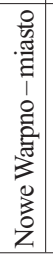 & 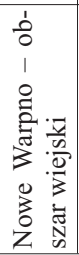 & 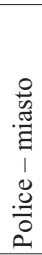 & 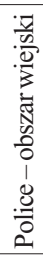 & 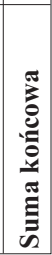 \\
\hline
\end{tabular}


$\frac{\sqrt{2}}{\frac{\pi}{8}}$

\begin{tabular}{|c|c|c|c|c|c|c|c|}
\hline 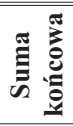 & $\begin{array}{l}8 \\
8 \\
0 \\
\text { D }\end{array}$ & $\begin{array}{l}0 \\
\text { in } \\
\text { a }\end{array}$ & $\begin{array}{l}\mathscr{6} \\
2 \\
2\end{array}$ & $\begin{array}{l}\tilde{c} \\
\sim \\
\sim\end{array} \mid$ & 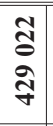 & $\begin{array}{l}\tilde{O} \\
\text { ¿े } \\
\varnothing\end{array}$ & 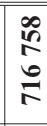 \\
\hline$\stackrel{\stackrel{\leftrightarrow}{\circ}}{\stackrel{\theta}{\theta}}$ & $\frac{2}{6}$ & $\underset{\infty}{\stackrel{f}{f}}$ & $\begin{array}{l}n \\
- \\
-\end{array}$ & gे & $\begin{array}{l}\vec{b} \\
0 \\
\dot{m}\end{array}$ & $\begin{array}{l}\infty \\
\infty \\
\infty \\
r\end{array}$ & $\begin{array}{l}\infty \\
\infty \\
\infty \\
\infty\end{array}$ \\
\hline $\begin{array}{l}8 \\
\stackrel{8}{8}\end{array}$ & $\begin{array}{l}\frac{n}{6} \\
6\end{array}$ & $\begin{array}{l}\stackrel{2}{i} \\
\infty\end{array}$ & $\frac{m}{n}$ & $\frac{n}{n}$ & $\begin{array}{c}\underset{J}{ \pm} \\
\underset{\sim}{\mathcal{N}}\end{array}$ & $\stackrel{\infty}{\stackrel{\infty}{n}}$ & $\begin{array}{l}8 \\
\text { ¿ } \\
\text { : }\end{array}$ \\
\hline $\begin{array}{l}\stackrel{8}{O} \\
\stackrel{\infty}{\circ}\end{array}$ & $\frac{i}{n}$ & $\underset{\sim}{\stackrel{N}{N}}$ & $\begin{array}{l}0 \\
8 \\
+ \\
-\end{array}$ & d & 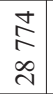 & $\begin{array}{l}\bar{a} \\
\hat{\sigma}\end{array}$ & 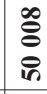 \\
\hline $\begin{array}{l}\stackrel{8}{8} \\
\text { s. }\end{array}$ & $\begin{array}{l}\mathscr{\wp} \\
\infty \\
+\end{array}$ & $\begin{array}{l}n \\
n \\
6\end{array}$ & $\stackrel{8}{\beth}$ & त & 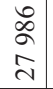 & 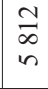 & $\begin{array}{l}\text { oे } \\
+ \\
\dot{+}\end{array}$ \\
\hline $\begin{array}{l}\stackrel{8}{8} \\
\stackrel{8}{\circ}\end{array}$ & 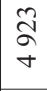 & $\frac{\circ}{\curvearrowleft}$ & $\overline{\check{a}}$ & $\stackrel{\mathcal{F}}{\mathrm{H}}$ & $\begin{array}{l}\infty \\
\infty \\
\infty \\
\sim\end{array} \mid$ & 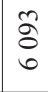 & $\frac{\infty}{\gamma}$ \\
\hline $\begin{array}{l}8 \\
\qquad \dot{8} \\
\qquad\end{array}$ & 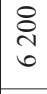 & $\underset{8}{f}$ & $\underset{\sim}{\stackrel{ }{\sim}}$ & $\bar{\sigma}$ & $\begin{array}{l}n \\
\bar{a} \\
\hat{\alpha}\end{array}$ & $\begin{array}{l}0 \\
0 \\
0 \\
0\end{array}$ & $\begin{array}{l}\text { ì } \\
\text { in } \\
\text { in }\end{array}$ \\
\hline $\begin{array}{l}\stackrel{\partial}{+} \\
\dot{\delta}\end{array}$ & 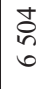 & $\begin{array}{l}\bar{n} \\
0\end{array}$ & 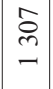 & & $\begin{array}{l}0 \\
⿱ \\
+ \\
\infty \\
\sim\end{array}$ & $\begin{array}{l}\infty \\
0 \\
0 \\
0\end{array}$ & $\begin{array}{l}\text { ర్ } \\
\infty \\
\infty\end{array}$ \\
\hline $\begin{array}{l}\stackrel{8}{0} \\
\text { ఠิ }\end{array}$ & $\begin{array}{l}\text { స్ } \\
\text { ర0 }\end{array}$ & 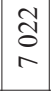 & 咲 & & $\begin{array}{l}\underset{尺}{ } \\
\text { ñ }\end{array}$ & $\underset{\nabla}{\exists}$ & $\begin{array}{l}\infty \\
\stackrel{8}{7} \\
i \\
i n\end{array}$ \\
\hline 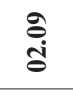 & ભે & $\begin{array}{l}n \\
\tilde{b} \\
0\end{array}$ & $\begin{array}{l}n \\
\infty \\
n \\
-\end{array}$ & & $\begin{array}{l}\infty \\
\infty \\
\infty \\
m \\
m\end{array}$ & $\stackrel{9}{=}$ & $\begin{array}{l}m \\
n \\
\dot{1} \\
\text { in }\end{array}$ \\
\hline $\begin{array}{l}\text { gे } \\
\text { gे }\end{array}$ & $\begin{array}{l}n \\
n \\
\infty \\
n\end{array}$ & $\stackrel{\substack{2 \\
r}}{2}$ & $\vec{\sigma}$ & & $\begin{array}{l}\stackrel{9}{1} \\
0 \\
n \\
m\end{array}$ & $\begin{array}{l}\stackrel{2}{N} \\
\stackrel{n}{r}\end{array}$ & $\frac{10}{6}$ \\
\hline 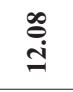 & $\begin{array}{l}\stackrel{0}{\circ} \\
\stackrel{+}{+} \\
\infty\end{array}$ & $\underset{\infty}{\stackrel{f}{ \pm}}$ & $\underline{\infty}$ & & $\begin{array}{l}a \\
0 \\
a \\
\text { n) }\end{array}$ & $\begin{array}{l}\hat{a} \\
\text { nิ } \\
\text { na }\end{array}$ & $\begin{array}{l}\overrightarrow{2} \\
\tilde{3}\end{array}$ \\
\hline$\stackrel{\infty}{\stackrel{0}{g}}$ & $\begin{array}{l}\vec{\sigma} \\
0 \\
0\end{array}$ & $\begin{array}{l}0 \\
\stackrel{2}{n} \\
r\end{array}$ & $\begin{array}{l}n \\
\sigma \\
n\end{array}$ & & $\begin{array}{l}1 \\
\delta \\
n \\
m\end{array}$ & $\begin{array}{l}\stackrel{\circ}{9} \\
\text { in }\end{array}$ & $\begin{array}{l}\hat{6} \\
+ \\
0 \\
i\end{array}$ \\
\hline 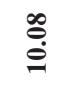 & $\stackrel{n}{r}$ & $\begin{array}{l}\stackrel{R}{n} \\
\infty\end{array}$ & $\stackrel{2}{2}$ & & $\begin{array}{l}\frac{\nabla}{m} \\
\vec{\nabla}\end{array}$ & $\underset{\infty}{\mathbb{N}}$ & $\frac{\hat{r}}{\hat{\sigma}}$ \\
\hline & 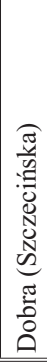 & 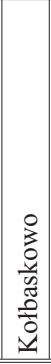 & 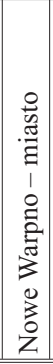 & 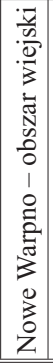 & 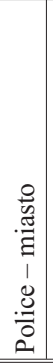 & 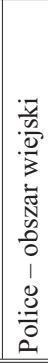 & 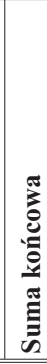 \\
\hline
\end{tabular}




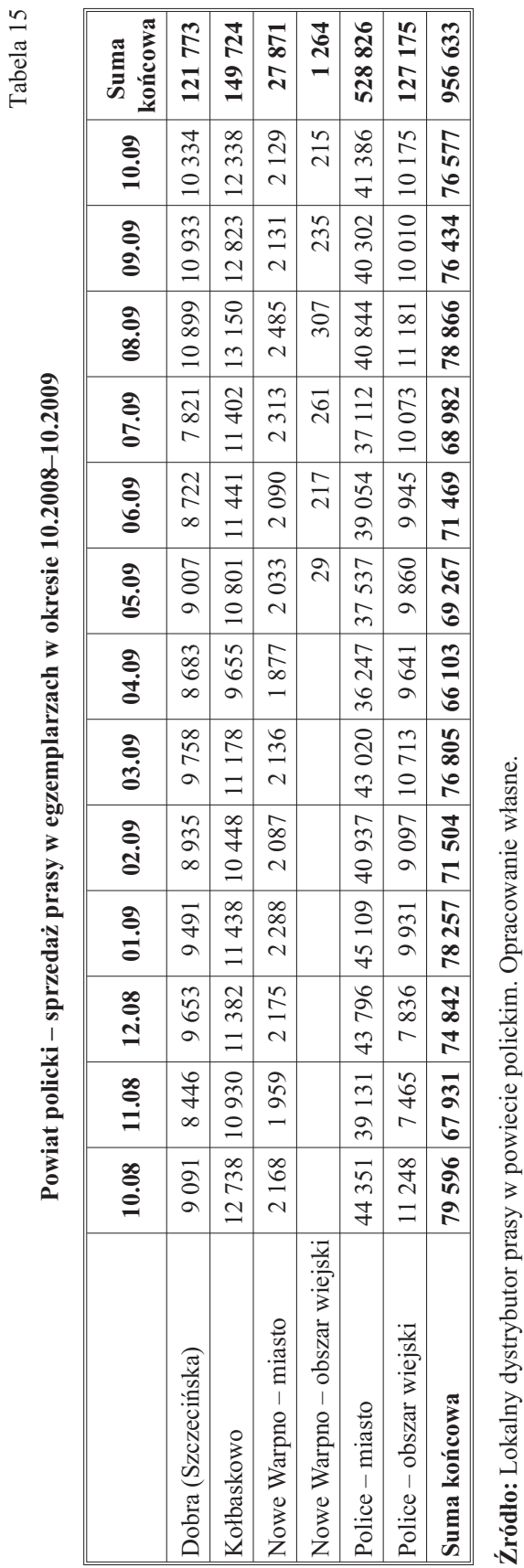


$\frac{1}{\frac{0}{0}}$

\begin{tabular}{|c|c|c|c|c|c|c|c|}
\hline 莙 & $\begin{array}{l}0 \\
0 \\
0 \\
8 \\
6\end{array}$ & $\begin{array}{l}\vec{m} \\
m \\
m\end{array}$ & $\begin{array}{l} \\
0 \\
0 \\
\infty \\
0 \\
0\end{array}$ & $\begin{array}{l}0 \\
\infty \\
r\end{array}$ & 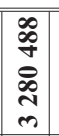 & 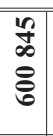 & $\begin{array}{l}\infty \\
2 \\
= \\
\bar{m} \\
n \\
n\end{array}$ \\
\hline$\stackrel{\stackrel{\leftrightarrow}{\Theta}}{\varrho}$ & 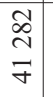 & $\begin{array}{l}\vec{B} \\
8\end{array}$ & 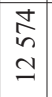 & $\vec{n}$ & 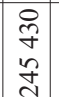 & 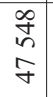 & $\begin{array}{l}\hat{\alpha} \\
\hat{\alpha} \\
\stackrel{\alpha}{\sigma}\end{array}$ \\
\hline $\begin{array}{l}\stackrel{8}{0} \\
\text { o }\end{array}$ & $\begin{array}{l}\stackrel{J}{\mathbb{Z}} \\
\tilde{f}\end{array}$ & $\begin{array}{l}\hat{A} \\
\tilde{0} \\
\stackrel{0}{0}\end{array}$ & $\begin{array}{l}g \\
g \\
=\end{array}$ & $\begin{array}{l}\text { શิ } \\
\text { n }\end{array}$ & $\begin{array}{l} \\
0 \\
0 \\
\tilde{d}\end{array}$ & $\begin{array}{l} \pm \\
\infty \\
i \\
\sigma\end{array}$ & 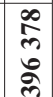 \\
\hline $\begin{array}{l}\stackrel{\circ}{0} \\
\dot{\theta}\end{array}$ & $\begin{array}{l}\stackrel{O}{+} \\
\sigma \\
F\end{array}$ & $\begin{array}{l}\tilde{o} \\
\alpha \\
\text { in }\end{array}$ & 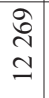 & $\begin{array}{l}\tilde{b} \\
\dot{d}\end{array}$ & 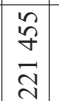 & $\begin{array}{l}\infty \\
\tilde{\sigma} \\
i \\
\dot{\sigma}\end{array}$ & $\begin{array}{l}\overline{\bar{n}} \\
\tilde{D} \\
\tilde{e}\end{array}$ \\
\hline $\begin{array}{l}\stackrel{8}{0} \\
\stackrel{5}{0}\end{array}$ & $\begin{array}{l} \pm \\
i \\
\sim \\
n \\
n\end{array}$ & $\begin{array}{l}0 \\
0 \\
\bar{n}\end{array}$ & $\begin{array}{l}0 \\
\infty \\
=\end{array}$ & $\begin{array}{l}\stackrel{0}{\infty} \\
\stackrel{\sim}{-}\end{array}$ & 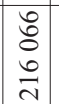 & $\begin{array}{l}\stackrel{m}{\sim} \\
\dot{y}\end{array}$ & 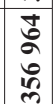 \\
\hline ठे. & $\begin{array}{l}n \\
\tilde{n} \\
\infty \\
n \\
n\end{array}$ & $\begin{array}{l}m \\
\tilde{N} \\
\tilde{n}\end{array}$ & $\begin{array}{l} \pm \\
8 \\
=\end{array}$ & $\stackrel{n}{n}$ & $\begin{array}{l}\hat{n} \\
\tilde{n} \\
n\end{array}$ & $\begin{array}{l}\infty \\
\infty \\
i \\
i\end{array}$ & 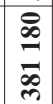 \\
\hline $\begin{array}{l}\stackrel{8}{\theta} \\
\ddot{\theta}\end{array}$ & $\begin{array}{l}\frac{\eta}{I} \\
F \\
F\end{array}$ & $\begin{array}{l}8 \\
n \\
8 \\
n\end{array}$ & $\begin{array}{l}\hat{b} \\
\infty \\
0 \\
0\end{array}$ & बे & $\begin{array}{l}0 \\
\dot{0} \\
\infty \\
\tilde{d} \\
\end{array}$ & $\begin{array}{l}+ \\
\tilde{c} \\
\infty \\
\infty \\
+\end{array}$ & $\begin{array}{l}\tilde{N} \\
\tilde{\alpha}\end{array}$ \\
\hline $\begin{array}{l}\stackrel{\partial}{0} \\
\dot{0}\end{array}$ & $\begin{array}{l}8 \\
8 \\
\text { mे }\end{array}$ & $\begin{array}{l}\mathscr{0} \\
0 \\
\dot{7} \\
7\end{array}$ & $\begin{array}{l}\mathcal{I} \\
\mathcal{O}\end{array}$ & & $\begin{array}{l}\stackrel{0}{0} \\
\stackrel{\sim}{\sim} \\
\sim\end{array}$ & $\begin{array}{l}\stackrel{0}{ } \\
8 \\
+\end{array}$ & $\frac{\vec{q}}{\vec{r}}$ \\
\hline $\begin{array}{l}\stackrel{8}{0} \\
\text { के }\end{array}$ & $\begin{array}{l}q \\
\dot{b} \\
F\end{array}$ & $\begin{array}{l}\stackrel{2}{a} \\
0 \\
i n\end{array}$ & $\begin{array}{l}\hat{a} \\
=\end{array}$ & & 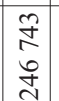 & $\begin{array}{l}\infty \\
\infty \\
\infty \\
\infty \\
+\end{array}$ & $\begin{array}{l}\text { İ } \\
\text { Oे } \\
\text { Oे }\end{array}$ \\
\hline $\begin{array}{l}\stackrel{\text { Oे }}{\text { İ }}\end{array}$ & $\begin{array}{l}m \\
\tilde{n} \\
\sim\end{array}$ & $\begin{array}{l}\quad \\
\delta \\
\bar{n}\end{array}$ & $\begin{array}{l}\exists \\
\text { I } \\
\text { I }\end{array}$ & & $\begin{array}{l}\tilde{n} \\
\infty \\
\delta \\
0 \\
\end{array}$ & $\begin{array}{l}\mathscr{D} \\
\infty \\
\tilde{F} \\
\infty\end{array}$ & $\begin{array}{l}0 \\
6 \\
0 \\
7\end{array}$ \\
\hline $\begin{array}{l}\stackrel{8}{0} \\
\text { }\end{array}$ & $\begin{array}{l}\vec{\infty} \\
\vec{f} \\
\vec{q}\end{array}$ & $\begin{array}{l}\vec{f} \\
\hat{m} \\
i n\end{array}$ & $\begin{array}{l}\overrightarrow{\tilde{p}} \\
\stackrel{v}{-}\end{array}$ & & $\begin{array}{l}\tilde{y} \\
\tilde{n} \\
\tilde{N} \\
\text { a }\end{array}$ & $\begin{array}{l}\varkappa \\
o \\
o \\
o+\end{array}$ & $\begin{array}{l}\hat{\infty} \\
\infty \\
8 \\
\dot{0}\end{array}$ \\
\hline 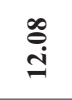 & $\begin{array}{l}\tilde{\delta} \\
\bar{\delta} \\
\bar{n}\end{array}$ & $\begin{array}{l}\infty \\
+ \\
0 \\
0\end{array}$ & $\begin{array}{l} \pm \\
\stackrel{J}{~} \\
\pm\end{array}$ & & $\begin{array}{l}\vec{n} \\
\infty \\
0 \\
0\end{array}$ & $\begin{array}{l}\text { I } \\
\text { V } \\
\text { q }\end{array}$ & $\begin{array}{l}n \\
2 \\
i n \\
f \\
f\end{array}$ \\
\hline$\stackrel{\infty}{\stackrel{\infty}{g}}$ & 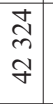 & $\begin{array}{l}g \\
\dot{G} \\
\dot{n} \\
\dot{n}\end{array}$ & $\begin{array}{l}\tilde{M} \\
\tilde{m} \\
\mathcal{I}\end{array}$ & & 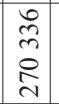 & $\begin{array}{l}\overrightarrow{\tilde{n}} \\
\infty \\
\tilde{n}\end{array}$ & $\begin{array}{l}n \\
\infty \\
5 \\
7\end{array}$ \\
\hline $\begin{array}{l}\stackrel{\infty}{\circ} \\
\stackrel{0}{0}\end{array}$ & 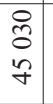 & $\begin{array}{l}0 \\
0 \\
0 \\
\text { V }\end{array}$ & $\begin{array}{l}\overrightarrow{8} \\
m \\
m\end{array}$ & & $\mid \begin{array}{l}0 \\
n \\
\tilde{n} \\
\tilde{e}\end{array}$ & \begin{tabular}{l}
$\infty$ \\
\multirow{7}{*}{} \\
$\tilde{n}$
\end{tabular} & $\begin{array}{l}\stackrel{8}{10} \\
\tilde{2} \\
\dot{2}\end{array}$ \\
\hline & 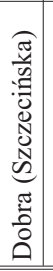 & 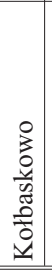 & 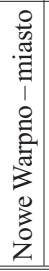 & 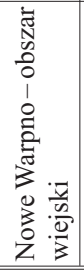 & 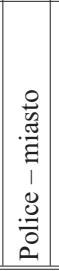 & 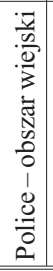 & 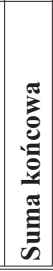 \\
\hline
\end{tabular}




\begin{tabular}{|c|c|c|c|c|c|c|c|c|}
\hline & 常 & 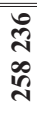 & $\begin{array}{l}\stackrel{\infty}{\infty} \\
\dot{+} \\
\dot{ల}\end{array}$ & 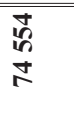 & $\begin{array}{l}\mathbb{N} \\
\infty \\
+\end{array}$ & $\begin{array}{l}\text { I } \\
\text { I } \\
\stackrel{N}{N}\end{array}$ & 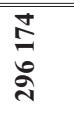 & 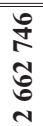 \\
\hline \multirow{14}{*}{ 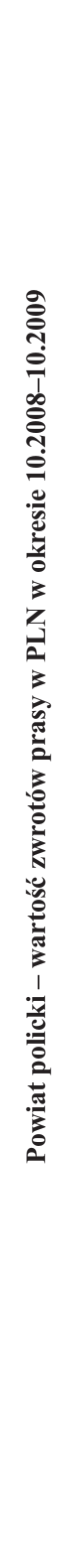 } & 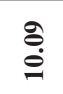 & 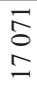 & $\begin{array}{l}\tilde{2} \\
\infty \\
\sim\end{array}$ & $\frac{\text { I }}{6}$ & $\stackrel{\infty}{0}$ & $\begin{array}{l}\tilde{b} \\
m \\
\infty \\
\text { In }\end{array}$ & $\frac{\bar{N}}{\tilde{N}}$ & 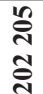 \\
\hline & $\begin{array}{l}\stackrel{\circ}{\circ} \\
\text { gे }\end{array}$ & 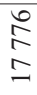 & $\begin{array}{l}\infty \\
\underset{\sim}{N} \\
\stackrel{\sim}{\sim}\end{array}$ & $\stackrel{m}{m}$ & $\stackrel{\infty}{\circ}$ & $\begin{array}{l}\tilde{n} \\
\tilde{n} \\
=\end{array}$ & 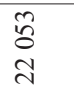 & $\begin{array}{l}\infty \\
\infty \\
\infty \\
\infty\end{array}$ \\
\hline & $\begin{array}{l}\stackrel{g}{\circ} \\
\stackrel{0}{\theta}\end{array}$ & $\begin{array}{l}\bar{\pi} \\
\text { ర్ర }\end{array}$ & $\begin{array}{l}\stackrel{8}{\text { mे }} \\
\vec{\sim}\end{array}$ & $\begin{array}{l}\stackrel{n}{0} \\
\infty \\
\forall\end{array}$ & I & $\begin{array}{l}\sqrt{n} \\
\hat{0}\end{array}$ & 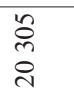 & 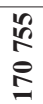 \\
\hline & 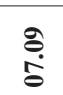 & $\begin{array}{l}\infty \\
\Xi \\
\Xi\end{array}$ & $\begin{array}{l}\infty \\
\stackrel{\infty}{n} \\
\stackrel{\sim}{\sim}\end{array}$ & $\begin{array}{l}\stackrel{P}{ } \\
0 \\
\forall\end{array}$ & $\stackrel{t}{6}$ & $\begin{array}{l}\infty \\
\infty \\
\infty \\
\stackrel{0}{0}\end{array}$ & 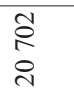 & $\frac{\sqrt{n}}{2}$ \\
\hline & 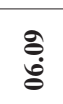 & $\begin{array}{l}\hat{\delta} \\
+ \\
0 \\
0\end{array}$ & 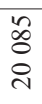 & $\frac{n}{n}$ & ปิ & $\begin{array}{l}\hat{a} \\
\stackrel{+}{=} \\
=\end{array}$ & $\begin{array}{l}\bar{a} \\
\tilde{a} \\
\text { and }\end{array}$ & $\begin{array}{l}0 \\
\infty \\
\infty\end{array}$ \\
\hline & 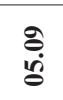 & $\begin{array}{l}\text { مे } \\
\text { nे } \\
2\end{array}$ & $\begin{array}{l}\dot{D} \\
0 \\
\bar{\sim}\end{array}$ & $\begin{array}{l}\vec{\nabla} \\
\forall \\
\forall\end{array}$ & $\stackrel{m}{m}$ & $\begin{array}{l}\mathbb{D} \\
\infty \\
\cong \\
\cong\end{array}$ & 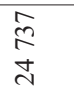 & 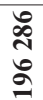 \\
\hline & $\begin{array}{l}\stackrel{\partial}{\circ} \\
\dot{0}\end{array}$ & $\begin{array}{l}\stackrel{0}{\infty} \\
\stackrel{2}{2}\end{array}$ & 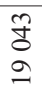 & 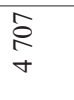 & & \begin{tabular}{l}
\multirow{2}{n}{} \\
$\infty$ \\
0
\end{tabular} & $\begin{array}{l}\stackrel{0}{2} \\
\stackrel{n}{N}\end{array}$ & $\begin{array}{l}\stackrel{2}{0} \\
\stackrel{0}{2}\end{array}$ \\
\hline & ڤે & $\frac{\infty}{2}$ & 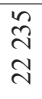 & $\begin{array}{l}\text { \& } \\
\text { in }\end{array}$ & & 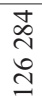 & $\begin{array}{l}\stackrel{3}{\beth} \\
\stackrel{\sim}{\mathfrak{n}}\end{array}$ & $\begin{array}{l}\tilde{g} \\
\stackrel{0}{0} \\
\stackrel{0}{0}\end{array}$ \\
\hline & 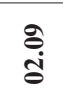 & $\begin{array}{l}+ \\
\text { i } \\
\text { రి }\end{array}$ & 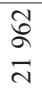 & $\vec{\Xi}$ & & $\begin{array}{l}\bar{m} \\
\text { n} \\
\stackrel{0}{n}\end{array}$ & $\begin{array}{l}\hat{n} \\
\text { ñ } \\
\text { ते }\end{array}$ & 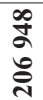 \\
\hline & बे. & $\begin{array}{l}\hat{0} \\
\infty \\
2 \\
\end{array}$ & 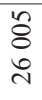 & $\frac{n}{i}$ & & 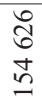 & $\begin{array}{l}\text { ¿ै } \\
\text { in } \\
\text { ป }\end{array}$ & $\stackrel{i}{i}$ \\
\hline & 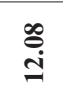 & 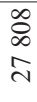 & $\begin{array}{l}\text { ते } \\
\text { ते } \\
\text { ते }\end{array}$ & 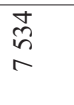 & & 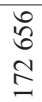 & $\begin{array}{l}\text { \&े } \\
\text { } \\
\text { ते }\end{array}$ & $\frac{\infty}{n}$ \\
\hline & $\stackrel{\infty}{\stackrel{\infty}{\Xi}}$ & $\begin{array}{l}\bar{a} \\
\bar{\alpha}\end{array}$ & $\begin{array}{l}\tilde{n} \\
\tilde{o} \\
n \\
n\end{array}$ & $\underset{\sim}{\infty}$ & & 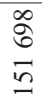 & $\begin{array}{l}\underset{T}{N} \\
\infty \\
\stackrel{\infty}{-}\end{array}$ & $\begin{array}{l}\vec{\infty} \\
\mathbb{N} \\
\widetilde{N}\end{array}$ \\
\hline & $\stackrel{\infty}{\stackrel{0}{0}}$ & $\begin{array}{l}\text { oे } \\
i n \\
\text { त }\end{array}$ & 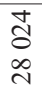 & $\frac{0}{n}$ & & $\begin{array}{l}\stackrel{+}{0} \\
\infty \\
\infty \\
0\end{array}$ & $\begin{array}{l}\stackrel{\infty}{\infty} \\
\stackrel{\lambda}{人}\end{array}$ & 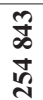 \\
\hline & & 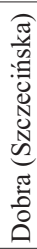 & $\begin{array}{l}0 \\
0 \\
0 \\
0 \\
0 \\
\tilde{z} \\
0 \\
0 \\
\underline{0}\end{array}$ & 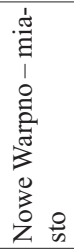 & 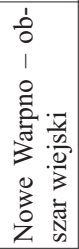 & 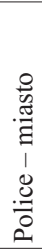 & 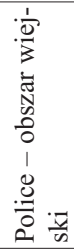 & 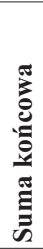 \\
\hline
\end{tabular}


$\frac{\infty}{\frac{\pi}{0}}$

\begin{tabular}{|c|c|c|c|c|c|c|c|}
\hline 焉 & $\begin{array}{l}\text { ปู } \\
\text { ป } \\
\text { ปิ }\end{array}$ & $\begin{array}{l}\infty \\
\infty \\
\infty \\
\infty \\
\dot{\sigma}\end{array}$ & $\begin{array}{l}\stackrel{\Xi}{\Xi} \\
\text { J }\end{array}$ & $\begin{array}{l}\infty_{\sim}^{\infty} \\
\sim\end{array}$ & $\begin{array}{l}\hat{0} \\
8 \\
0 \\
0 \\
n \\
-\end{array}$ & 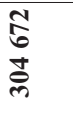 & 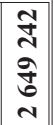 \\
\hline 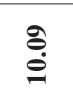 & $\begin{array}{l}\Xi \\
\sim \\
\stackrel{\sim}{\sim}\end{array}$ & $\begin{array}{l}\infty \\
\stackrel{\infty}{r} \\
\dot{m}\end{array}$ & $\begin{array}{l}\tilde{v} \\
\forall \\
\sigma\end{array}$ & d্ & $\begin{array}{l}\mathfrak{2} \\
\vdots \\
\Xi \\
=\end{array}$ & $\begin{array}{l}\overrightarrow{\tilde{D}} \\
\ddot{\sim}\end{array}$ & 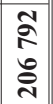 \\
\hline $\begin{array}{l}\stackrel{\partial}{\dot{\theta}} \\
\stackrel{\theta}{ }\end{array}$ & $\begin{array}{l}\stackrel{\vartheta}{f} \\
\stackrel{y}{a} \\
\sim\end{array}$ & $\begin{array}{l}8 \\
8 \\
0 \\
\text { r }\end{array}$ & $\begin{array}{l}\stackrel{8}{8} \\
\text { ర } \\
0\end{array}$ & in & $\begin{array}{l}\overrightarrow{3} \\
0 \\
=\end{array}$ & $\begin{array}{l}\vec{b} \\
\ddot{\sim}\end{array}$ & $\begin{array}{l}\stackrel{\partial}{0} \\
\stackrel{\partial}{\hat{~}}\end{array}$ \\
\hline $\begin{array}{l}\stackrel{O}{0} \\
\stackrel{0}{0}\end{array}$ & $\begin{array}{l}\vec{\sigma} \\
\tilde{n}\end{array}$ & $\begin{array}{l}\mathcal{N} \\
\tilde{n} \\
\infty \\
n\end{array}$ & $\underset{\sim}{\stackrel{\sim}{\sim}}$ & $\stackrel{N}{N}$ & $\begin{array}{l} \pm \\
\text { D } \\
\pm \\
\Xi\end{array}$ & 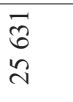 & $\begin{array}{l}\stackrel{\circ}{1} \\
\text { 웡 }\end{array}$ \\
\hline$\underset{\stackrel{8}{\circ}}{\stackrel{8}{8}}$ & $\begin{array}{l}\tilde{n} \\
\tilde{\sigma} \\
\infty \\
-\end{array}$ & $\begin{array}{l}\tilde{W} \\
\infty \\
0 \\
\infty\end{array}$ & $\begin{array}{l}\stackrel{D}{n} \\
\sim\end{array}$ & $\bar{\sigma}$ & 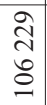 & $\begin{array}{l}\stackrel{0}{n} \\
\ddot{n}\end{array}$ & $\begin{array}{l}m \\
\infty \\
\infty \\
0 \\
\infty\end{array}$ \\
\hline $\begin{array}{l}\stackrel{g}{\circ} \\
\stackrel{0}{8}\end{array}$ & $\begin{array}{l}\hat{\delta} \\
\text { ते } \\
\vec{v}\end{array}$ & $\begin{array}{l}\infty \\
\text { d } \\
\text { v } \\
n\end{array}$ & $\underset{v}{\tilde{f}}$ & రु & $\begin{array}{l}\stackrel{9}{ } \\
0 \\
m \\
=\end{array}$ & $\begin{array}{l}\hat{\sigma} \\
\tilde{a} \\
\ddot{n}\end{array}$ & $\begin{array}{l}\vec{\Xi} \\
\vdots \\
\hat{\sigma}\end{array}$ \\
\hline $\begin{array}{l}\stackrel{8}{0} \\
\ddot{\theta}\end{array}$ & $\begin{array}{l}\stackrel{i}{n} \\
\text { त) }\end{array}$ & $\begin{array}{l}\hat{8} \\
\text { ते } \\
\text { aे }\end{array}$ & $\begin{array}{l}\text { ָे } \\
\text { రิ }\end{array}$ & $\dot{n}$ & $\begin{array}{l}0 \\
\stackrel{0}{\beth} \\
\Xi\end{array}$ & $\begin{array}{l}\hat{\curvearrowright} \\
\hat{\imath}\end{array}$ & 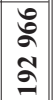 \\
\hline $\begin{array}{l}\stackrel{g}{\partial} \\
\dot{\theta}\end{array}$ & $\begin{array}{l}\tilde{\infty} \\
\text { N } \\
\stackrel{\sim}{N}\end{array}$ & 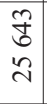 & $\begin{array}{l}\stackrel{n}{f} \\
\dot{f} \\
n\end{array}$ & & $\begin{array}{l}\tilde{N} \\
\tilde{n} \\
\vdots \\
0\end{array}$ & $\begin{array}{l}\vec{y} \\
\stackrel{2}{N} \\
\text { N }\end{array}$ & 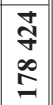 \\
\hline$\underset{\text { है }}{\stackrel{8}{0}}$ & $\begin{array}{l}8 \\
\stackrel{0}{+} \\
\stackrel{1}{2}\end{array}$ & $\begin{array}{l}\stackrel{ \pm}{\sim} \\
n \\
\infty \\
\sim\end{array}$ & $\hat{n}$ & & 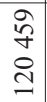 & $\begin{array}{l}\tilde{b} \\
\infty \\
\tilde{\lambda}\end{array}$ & 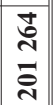 \\
\hline $\begin{array}{l}\stackrel{g}{\partial} \\
\text { ฮ̀ }\end{array}$ & $\begin{array}{l}\text { ते } \\
\text { ते }\end{array}$ & 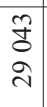 & 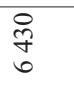 & & $\begin{array}{l}0 \\
\sim \\
\sim \\
\beth\end{array}$ & $\begin{array}{l}\hat{a} \\
\vec{a}\end{array}$ & 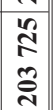 \\
\hline$\frac{\stackrel{\theta}{\theta}}{\text { ọ }}$ & $\begin{array}{l}\infty \\
\sigma \\
\sim \\
\sim\end{array}$ & $\begin{array}{l}\text { Dn } \\
\text { m} \\
\text { m }\end{array}$ & $\frac{0}{i}$ & & $\begin{array}{l}0 \\
a \\
\hat{n}\end{array}$ & $\begin{array}{l}\hat{n} \\
\hat{n}\end{array}$ & 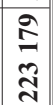 \\
\hline $\begin{array}{l}\infty \\
\stackrel{\leftrightarrow}{త}\end{array}$ & $\begin{array}{l}\stackrel{ \pm}{2} \\
\stackrel{2}{2}\end{array}$ & $\begin{array}{l}\hat{\Upsilon} \\
\bar{r}\end{array}$ & 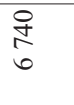 & & $\begin{array}{l} \pm \\
\stackrel{\Xi}{2} \\
n\end{array}$ & $\begin{array}{l}\vec{\sim} \\
\stackrel{\sim}{\sim}\end{array}$ & $\begin{array}{l}\stackrel{N}{N} \\
\stackrel{\sim}{N}\end{array}$ \\
\hline$\stackrel{\infty}{\stackrel{\infty}{ٍ}}$ & $\begin{array}{l}\text { mे } \\
\text { mे } \\
\stackrel{\sim}{N}\end{array}$ & $\begin{array}{l}\text { मे } \\
\text { ڤે } \\
\text { ते }\end{array}$ & $\begin{array}{l}n \\
\delta \\
0\end{array}$ & & $\begin{array}{l}\infty \\
\tilde{6} \\
\infty \\
=\end{array}$ & $\begin{array}{l}\stackrel{\infty}{\infty} \\
\dot{+} \\
\stackrel{2}{+}\end{array}$ & 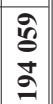 \\
\hline$\stackrel{\infty}{\stackrel{0}{\circ}}$ & $\begin{array}{l}\vec{\sim} \\
\tilde{N} \\
\widetilde{v}\end{array}$ & $\begin{array}{l}0 \\
2 \\
0 \\
\dot{n} \\
m\end{array}$ & \begin{tabular}{l}
\multirow{4}{*}{} \\
ñ
\end{tabular} & & 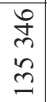 & $\begin{array}{l}\text { ळे } \\
\infty \\
\text { ते }\end{array}$ & 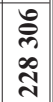 \\
\hline & 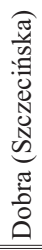 & $\begin{array}{l}0 \\
\vdots \\
0 \\
\frac{0}{0} \\
\tilde{0} \\
\overline{0} \\
\underline{v}\end{array}$ & 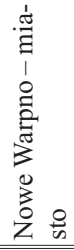 & 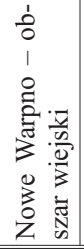 & 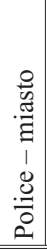 & 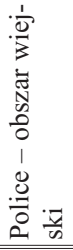 & 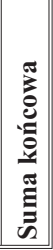 \\
\hline
\end{tabular}


Wartość sprzedaży prasy w poszczególnych gminach wygląda następująco: Police - miasto 58,74\%, Kołbaskowo 15,43\%, Police - obszar wiejski $11,50 \%$, gmina Dobra $11,05 \%$, Nowe Warpno - miasto 3,17\% i Nowe Warpno - obszar wiejski $0,11 \%$.

W kolejnej części wyliczeń dystrybucji płatnej w powiecie polickim, precyzowane są informacje o liczbie punktów sprzedaży detalicznej prasy.

Tabela 19 dokumentuje maksymalną liczbę punktów sprzedaży zlokalizowanych na terenie poszczególnych gmin.

Tabela 19

Powiat policki - liczba punktów sieci sprzedaży detalicznej prasy (maksymalna) w okresie 10.2008-10.2009

\begin{tabular}{|c|c|c|c|c|c|c|c|c|c|c|c|c|c|c|}
\hline & $\begin{array}{l}\stackrel{\infty}{\stackrel{0}{\ominus}} \\
\stackrel{0}{0}\end{array}$ & $\stackrel{\infty}{\stackrel{\infty}{=}}$ & $\begin{array}{l}\infty \\
\stackrel{0}{\beth} \\
\end{array}$ & $\begin{array}{l}\stackrel{g}{\dot{\theta}} \\
\text {. }\end{array}$ & 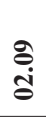 & $\begin{array}{l}\stackrel{\partial}{0} \\
\text { s. }\end{array}$ & $\begin{array}{l}\hat{\theta} \\
\dot{\theta}\end{array}$ & $\begin{array}{l}\stackrel{\dot{\theta}}{\theta} \\
\dot{\theta}\end{array}$ & $\begin{array}{l}\stackrel{\partial}{\dot{b}} \\
\stackrel{0}{0}\end{array}$ & $\begin{array}{l}\stackrel{8}{5} \\
\stackrel{5}{0}\end{array}$ & $\begin{array}{l}\stackrel{\leftrightarrow}{\dot{\theta}} \\
\dot{8}\end{array}$ & $\begin{array}{l}\hat{\theta} \\
\hat{8}\end{array}$ & 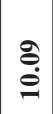 & $\begin{array}{l}\text { Suma } \\
\text { koń- } \\
\text { cowa }\end{array}$ \\
\hline Dobra (Szcz & 7 & 8 & 8 & 8 & 8 & 8 & 8 & 8 & 8 & 6 & 7 & 7 & 7 & 8 \\
\hline Kołbaskowo & 7 & 7 & 7 & 7 & 7 & 7 & 7 & 8 & 8 & 8 & 9 & 9 & 9 & 9 \\
\hline Nowe Warpno - miasto & 1 & 1 & 1 & 1 & 1 & 1 & 1 & 1 & 1 & 1 & 2 & 1 & 1 & 1 \\
\hline $\begin{array}{l}\text { Nowe Warpno - obszar } \\
\text { wiejski }\end{array}$ & & & & & & & & 1 & 1 & 1 & 1 & 1 & 1 & 1 \\
\hline Police - miasto & 23 & 23 & 23 & 23 & 23 & 23 & 22 & 22 & 22 & 22 & 24 & 22 & 23 & 24 \\
\hline Police - obszar wiejski & 7 & 7 & 5 & 6 & 6 & 6 & 6 & 6 & 6 & 6 & 6 & 6 & 6 & 7 \\
\hline Suma końcowa & 23 & 23 & 23 & 23 & 23 & 23 & 22 & 22 & 22 & 22 & 24 & 22 & 23 & 24 \\
\hline
\end{tabular}

Źródło: Lokalny dystrybutor prasy w powiecie polickim. Opracowanie własne.

Największa liczba punktów sieci sprzedaży detalicznej prasy wynosiła odpowiednio: Police - miasto 24, Kołbaskowo 9, Dobra 8, Police - obszar wiejski 7, Nowe Warpno - miasto 2 i Nowe Warpno - obszar wiejski 1 .

Tabela 20 natomiast zawiera minimalną liczbę punktów sprzedaży, zlokalizowanych na terenie poszczególnych gmin.

Najmniejsza liczba punktów sieci sprzedaży detalicznej prasy wynosiła odpowiednio: Police - miasto 1, Kołbaskowo 1, Dobra 0, Police - obszar wiejski 0, Nowe Warpno - miasto 1 i Nowe Warpno - obszar wiejski 1 .

Tabela 21 wykazuje maksymalną liczbę czynnych punktów sprzedaży, do których został skierowany nadział tytułów prasowych. 
Tabela 20

Powiat policki - liczba punktów sieci sprzedaży detalicznej prasy (minimalna) w okresie 10.2008-10.2009

\begin{tabular}{|c|c|c|c|c|c|c|c|c|c|c|c|c|c|c|}
\hline & $\stackrel{\infty}{\stackrel{0}{\ominus}}$ & $\stackrel{\infty}{\stackrel{\infty}{二}}$ & $\stackrel{\infty}{\stackrel{\infty}{+}}$ & बें & $\begin{array}{l}\stackrel{g}{\mathrm{i}} \\
\stackrel{8}{ }\end{array}$ & है. & $\begin{array}{l}\stackrel{g}{g} \\
\dot{g}\end{array}$ & 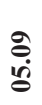 & 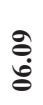 & $\frac{8}{\circ}$ & $\begin{array}{l}\stackrel{g}{\circ} \\
\stackrel{\infty}{\circ}\end{array}$ & $\begin{array}{l}\stackrel{\circ}{\circ} \\
\stackrel{8}{\circ}\end{array}$ & $\stackrel{\varrho}{\stackrel{\theta}{\theta}}$ & $\begin{array}{c}\text { Suma } \\
\text { koń- } \\
\text { cowa }\end{array}$ \\
\hline Dobra (Szczecińska) & 1 & 1 & 1 & 1 & 1 & 1 & 1 & 1 & 1 & 0 & 0 & 0 & 1 & $\mathbf{0}$ \\
\hline Kołbaskowo & 1 & 1 & 1 & 1 & 1 & 1 & 1 & 1 & 1 & 1 & 1 & 1 & 1 & 1 \\
\hline Nowe Warpno - miasto & 1 & 1 & 1 & 1 & 1 & 1 & 1 & 1 & 1 & 1 & 1 & 1 & 1 & 1 \\
\hline $\begin{array}{l}\text { Nowe Warpno - obszar } \\
\text { wiejski }\end{array}$ & & & & & & & & 1 & 1 & 1 & 1 & 1 & 1 & 1 \\
\hline Police - miasto & 1 & 1 & 1 & 1 & 1 & 1 & 1 & 1 & 1 & 1 & 1 & 1 & 1 & 1 \\
\hline Police - obszar wiejski & 0 & 0 & 1 & 0 & 1 & 1 & 1 & 1 & 1 & 1 & 1 & 1 & 1 & $\mathbf{0}$ \\
\hline Suma końcowa & $\mathbf{0}$ & $\mathbf{0}$ & 1 & $\mathbf{0}$ & 1 & 1 & 1 & 1 & 1 & $\mathbf{0}$ & $\mathbf{0}$ & $\mathbf{0}$ & 1 & $\mathbf{0}$ \\
\hline
\end{tabular}

Źródło: Lokalny dystrybutor prasy w powiecie polickim. Opracowanie własne.

Tabela 21

Powiat policki - ilość punktów czynnych sieci sprzedaży detalicznej prasy (maksymalna) w okresie 10.2008-10.2009

\begin{tabular}{|c|c|c|c|c|c|c|c|c|c|c|c|c|c|c|}
\hline & $\stackrel{\infty}{\stackrel{\infty}{\circ}}$ & $\stackrel{\infty}{\stackrel{\infty}{\ominus}}$ & 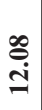 & $\stackrel{\stackrel{g}{\dot{\theta}}}{ }$ & $\begin{array}{c}\stackrel{g}{\text { iे }} \\
\text { ฮे }\end{array}$ & $\stackrel{g}{\ddot{\theta}}$ & $\begin{array}{l}\stackrel{g}{\dot{\theta}} \\
\dot{\theta}\end{array}$ & $\begin{array}{l}\mathscr{8} \\
\ddot{\theta}\end{array}$ & @़े & 产 & $\begin{array}{l}\stackrel{\circ}{\circ} \\
\stackrel{\infty}{\circ}\end{array}$ & $\begin{array}{l}\stackrel{\circ}{\circ} \\
\stackrel{g}{\circ}\end{array}$ & 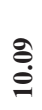 & $\begin{array}{c}\text { Suma } \\
\text { koń- } \\
\text { cowa }\end{array}$ \\
\hline Dobra (Szczecińska) & 7 & 8 & 8 & 8 & 8 & 8 & 8 & 8 & 8 & 8 & 13 & 8 & 7 & 8 \\
\hline Kołbaskowo & 7 & 7 & 7 & 7 & 7 & 7 & 7 & 8 & 8 & 8 & 17 & 9 & 9 & 17 \\
\hline Nowe Warpno - miasto & 1 & 1 & 1 & 1 & 1 & 1 & 1 & 1 & 1 & 1 & 2 & 1 & 1 & 2 \\
\hline $\begin{array}{l}\text { Nowe Warpno - obszar } \\
\text { wiejski }\end{array}$ & & & & & & & & 1 & 1 & 1 & 1 & 1 & 1 & 1 \\
\hline Police - miasto & 24 & 23 & 23 & 23 & 23 & 23 & 23 & 23 & 23 & 23 & 42 & 22 & 23 & 24 \\
\hline Police - obszar wiejski & 7 & 7 & 7 & 7 & 7 & 6 & 6 & 6 & 6 & 6 & 12 & 6 & 6 & 6 \\
\hline Suma końcowa & 7 & 6 & 6 & 6 & 6 & 6 & 23 & 23 & 23 & 23 & 22 & 22 & 23 & 24 \\
\hline
\end{tabular}

Źródło: Lokalny dystrybutor prasy w powiecie polickim. Opracowanie własne.

Maksymalna liczba czynnych punktów sprzedaży detalicznej prasy: Police - miasto 24, Kołbaskowo 17, Dobra 8, Police - obszar wiejski 6, Nowe Warpno - miasto 2 i Nowe Warpno - obszar wiejski 1.

Zaś tabela 22 pokazuje minimalną liczbę czynnych punktów sprzedaży prasy, do których został skierowany nadział tytułów prasowych. 
Tabela 22

Powiat policki - liczba punktów sieci sprzedaży detalicznej prasy (minimalna) w okresie 10.2008-10.2009

\begin{tabular}{|c|c|c|c|c|c|c|c|c|c|c|c|c|c|c|}
\hline & $\stackrel{\infty}{\stackrel{0}{0}}$ & $\stackrel{\infty}{\stackrel{\infty}{\circ}}$ & $\stackrel{\infty}{\stackrel{\infty}{+}}$ & 官 & 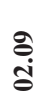 & $\begin{array}{l}\stackrel{g}{\circ} \\
\text { ตे }\end{array}$ & $\begin{array}{l}\stackrel{g}{\dot{\theta}} \\
\dot{\dot{\theta}}\end{array}$ & $\begin{array}{l}\text { gे } \\
\text { हैं }\end{array}$ & 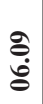 & 产 & $\begin{array}{l}\stackrel{8}{8} \\
\text { o }\end{array}$ & $\begin{array}{l}\stackrel{\circ}{\circ} \\
\stackrel{8}{8}\end{array}$ & $\begin{array}{l}\stackrel{\circ}{\circ} \\
\stackrel{\theta}{\theta}\end{array}$ & $\begin{array}{l}\text { Suma } \\
\text { koń- } \\
\text { cowa }\end{array}$ \\
\hline Dobra (Szczecińska) & 5 & 5 & 6 & 6 & 6 & 6 & 6 & 6 & 6 & 6 & 6 & 6 & 6 & 5 \\
\hline Kołbaskowo & 7 & 7 & 7 & 7 & 7 & 7 & 7 & 7 & 7 & 7 & 7 & 8 & 8 & 7 \\
\hline Nowe Warpno - miasto & 1 & 1 & 1 & 1 & 1 & 1 & 1 & 1 & 1 & 1 & 1 & 1 & 1 & 1 \\
\hline $\begin{array}{l}\text { Nowe Warpno - obszar } \\
\text { wiejski }\end{array}$ & & & & & & & & 1 & 1 & 1 & 1 & 1 & 1 & 1 \\
\hline Police - miasto & 22 & 21 & 21 & 20 & 20 & 19 & 19 & 19 & 19 & 20 & 20 & 20 & 20 & 20 \\
\hline Police - obszar wiejski & 6 & 5 & 5 & 5 & 5 & 5 & 5 & 5 & 6 & 5 & 6 & 5 & 5 & 5 \\
\hline Suma końcowa & 6 & 5 & 5 & 5 & 5 & 5 & 1 & 1 & 1 & 1 & 6 & 1 & 1 & 1 \\
\hline
\end{tabular}

Źródło: Lokalny dystrybutor prasy w powiecie polickim. Opracowanie własne.

Minimalna liczba czynnych punktów sprzedaży detalicznej: Police miasto 20, Kołbaskowo 7, Dobra 5, Police - obszar wiejski 5, Nowe Warpno - miasto 1 i Nowe Warpno - obszar wiejski 1.

Ostatnia część opisuje wcześniejsze omówione dane pod kątem periodyczności. Przyjęto klasyfikację częstotliwości ukazywania się tytułów prasowych dystrybutora prasy.

Tabela 23 przedstawia liczbę wydań prasy oraz jej periodyczność.

Tabela 23

Powiat policki - liczba wydań i periodyczność prasy w okresie 10.2008-10.2009

\begin{tabular}{||l|c|c|c|c|c|c|c||}
\hline \hline & $\begin{array}{c}\text { Dobra } \\
\text { (Szcze- } \\
\text { cińska) }\end{array}$ & $\begin{array}{c}\text { Kołbas- } \\
\text { kowo }\end{array}$ & $\begin{array}{c}\text { Nowe } \\
\text { Warpno } \\
\text { miasto }\end{array}$ & $\begin{array}{c}\text { Nowe } \\
\text { Warpno } \\
\text { obszar } \\
\text { wiejski }\end{array}$ & $\begin{array}{c}\text { Police } \\
\text { miasto }\end{array}$ & $\begin{array}{c}\text { Police } \\
- \text { obszar } \\
\text { wiejski }\end{array}$ & $\begin{array}{c}\text { Suma } \\
\text { końco- } \\
\text { wa }\end{array}$ \\
\hline 1 & 2 & 3 & 4 & 5 & 6 & 7 & 8 \\
\hline $\begin{array}{l}\text { Czasopismo ukazujące } \\
\text { się 2 razy w miesiącu }\end{array}$ & 42 & 54 & 13 & & 135 & 69 & $\mathbf{3 1 3}$ \\
\hline $\begin{array}{l}\text { Czasopismo ukazujące } \\
\text { się 3 razy w miesiącu }\end{array}$ & 11 & 32 & 25 & & 59 & 34 & $\mathbf{1 6 1}$ \\
\hline Dwutygodnik & 2750 & 3558 & 2130 & 97 & 6379 & 3790 & $\mathbf{1 8 7 0 4}$ \\
\hline $\begin{array}{l}\text { Dziennik ukazujący się } \\
\text { 2 razy w tygodniu }\end{array}$ & 536 & 752 & 566 & 58 & 1171 & 737 & $\mathbf{3 ~ 8 2 0}$ \\
\hline $\begin{array}{l}\text { Dziennik ukazujący się } \\
\text { 3 razy w tygodniu }\end{array}$ & 2885 & 3415 & 2476 & 333 & 4812 & 3583 & $\mathbf{1 7 5 0 4}$ \\
\hline
\end{tabular}




\begin{tabular}{||l|r|r|r|r|r|r|r||}
\hline \multicolumn{1}{|c|}{1} & \multicolumn{1}{c|}{2} & \multicolumn{1}{c|}{3} & \multicolumn{1}{c|}{4} & \multicolumn{1}{c|}{5} & \multicolumn{1}{c|}{6} & \multicolumn{1}{c|}{7} & \multicolumn{1}{c||}{8} \\
\hline $\begin{array}{l}\text { Dziennik ukazujący się } \\
\text { 7 razy w tygodniu }\end{array}$ & 3982 & 3985 & 3343 & 572 & 4062 & 3765 & $\mathbf{1 9 7 0 9}$ \\
\hline Miesięcznik & 1387 & 2022 & 1365 & 5 & 3972 & 2063 & $\mathbf{1 0 ~ 8 1 4}$ \\
\hline Trzytygodnik & 284 & 306 & 211 & & 917 & 417 & $\mathbf{2 ~ 1 3 5}$ \\
\hline Tygodnik & 240 & 465 & 279 & 4 & 1292 & 581 & $\mathbf{2 ~ 8 6 1}$ \\
\hline Suma końcowa & $\mathbf{1 2 ~ 1 1 7}$ & $\mathbf{1 4 5 8 9}$ & $\mathbf{1 0 4 0 8}$ & $\mathbf{1 0 6 9}$ & $\mathbf{2 2 ~ 7 9 9}$ & $\mathbf{1 5 0 3 9}$ & $\mathbf{7 6 ~ 0 2 1}$ \\
\hline
\end{tabular}

Źródło: Lokalny dystrybutor prasy w powiecie polickim. Opracowanie własne.

Najwięcej było wydań: dzienników ukazujących się 7 dni w tygodniu $25,93 \%$, dwutygodników 24,60\%, dzienników ukazujących się 3 razy w tygodniu 23,03\%, miesięczników 14,23\%. Dalej, dziennik ukazujący się 2 razy w tygodniu 5,02\%, tygodniki 3,76\%, trzytygodniki 2,81\%, czasopismo ukazujące się 2 razy w miesiącu $0,41 \%$ i 3 razy w miesiącu $0,21 \%$.

Tabela 24 zawiera wielkość nakładów prasy według periodyczności.

Tabela 24

Powiat policki - wielkość nakładów prasy w egzemplarzach według periodyczności w okresie 10.2008-10.2009

\begin{tabular}{|c|c|c|c|c|c|c|c|}
\hline & $\begin{array}{l}\text { Dobra } \\
\text { (Szcze- } \\
\text { cińska) }\end{array}$ & $\begin{array}{c}\text { Kolbas- } \\
\text { kowo }\end{array}$ & $\begin{array}{c}\text { Nowe } \\
\text { Warpno } \\
\text { miasto }\end{array}$ & $\begin{array}{c}\text { Nowe } \\
\text { Warpno } \\
\text { obszar } \\
\text { wiejski }\end{array}$ & $\begin{array}{l}\text { Police - } \\
\text { miasto }\end{array}$ & $\begin{array}{c}\text { Police - } \\
\text { obszar } \\
\text { wiejski }\end{array}$ & $\begin{array}{l}\text { Suma } \\
\text { koń- } \\
\text { cowa }\end{array}$ \\
\hline $\begin{array}{l}\text { Czasopismo ukazujące } \\
\text { się } 2 \text { razy w miesiącu }\end{array}$ & 77 & 189 & 29 & & 1292 & 225 & 1812 \\
\hline $\begin{array}{l}\text { Czasopismo ukazujące } \\
\text { się } 3 \text { razy w miesiącu }\end{array}$ & 36 & 110 & 75 & & 986 & 129 & 1812 \\
\hline Dwutygodnik & 20155 & 29314 & 6490 & 356 & 141336 & 23820 & 221471 \\
\hline $\begin{array}{l}\text { Dziennik ukazujący się } \\
2 \text { razy w tygodniu }\end{array}$ & 7288 & 12199 & 2746 & 183 & 39599 & 9167 & 71182 \\
\hline $\begin{array}{l}\text { Dziennik ukazujący się } \\
3 \text { razy w tygodniu }\end{array}$ & 54799 & 69871 & 15613 & 1377 & 269355 & 63855 & 474870 \\
\hline $\begin{array}{l}\text { Dziennik ukazujący się } \\
7 \text { razy w tygodniu }\end{array}$ & 115615 & 121208 & 18112 & 1585 & 401105 & 103195 & 760820 \\
\hline Miesięcznik & 6250 & 8220 & 3362 & 14 & 80038 & 9544 & 107428 \\
\hline Trzytygodnik & 1272 & 1313 & 486 & & 11314 & 1785 & 16170 \\
\hline Tygodnik & 881 & 1876 & 653 & 12 & 12823 & 2057 & 18302 \\
\hline Suma końcowa & 206373 & 244300 & 47566 & 3527 & 957848 & 213777 & 1673391 \\
\hline
\end{tabular}

Źródło: Lokalny dystrybutor prasy w powiecie polickim. Opracowanie własne. 
Największe nakłady egzemplarzowe prasy odnotowuje się dla: dzienników ukazujących się 7 dni w tygodniu 45,47\%, dzienników ukazujących się 3 razy w tygodniu $28,38 \%$, dwutygodników $13,23 \%$, miesięczników $6,42 \%$, 2 razy w tygodniu 4,25\%, tygodniki 1,09\%, trzytygodniki $0,97 \%$, czasopismo ukazujące się 2 razy w miesiącu $0,11 \%$ i 3 razy w miesiącu $0,08 \%$.

W tabeli 25 ujęta jest wielkość zwrotów tytułów prasowych według periodyczności.

Tabela 25

Powiat policki - wielkość zwrotów prasy w egzemplarzach według periodyczności w okresie 10.2008-10.2009

\begin{tabular}{||r|r|r|r|r|r|r|r||}
\hline & $\begin{array}{c}\text { Dobra } \\
\text { (Szcze- } \\
\text { cińska) }\end{array}$ & $\begin{array}{c}\text { Kolbas- } \\
\text { kowo }\end{array}$ & $\begin{array}{c}\text { Nowe } \\
\text { Warpno } \\
\text { miasto }\end{array}$ & $\begin{array}{c}\text { Nowe } \\
\text { Warpno } \\
\text { obszar } \\
\text { wiejski }\end{array}$ & $\begin{array}{c}\text { Police - } \\
\text { miasto }\end{array}$ & $\begin{array}{c}\text { Police - } \\
\text { obszar } \\
\text { wiejski }\end{array}$ & $\begin{array}{c}\text { Suma } \\
\text { końcowa }\end{array}$ \\
\hline $\begin{array}{l}\text { Czasopismo ukazujące } \\
\text { się 2 razy w miesiącu }\end{array}$ & 54 & 127 & 17 & & 987 & 147 & $\mathbf{1 3 3 2}$ \\
\hline $\begin{array}{l}\text { Czasopismo ukazujące } \\
\text { się 3 razy w miesiącu }\end{array}$ & 22 & 83 & 50 & & 602 & 79 & $\mathbf{8 3 6}$ \\
\hline Dwutygodnik & 10284 & 12182 & 3284 & 169 & 77134 & 12949 & $\mathbf{1 1 6} \mathbf{0 0 2}$ \\
\hline $\begin{array}{l}\text { Dziennik ukazujący się } \\
\text { 2 razy w tygodniu }\end{array}$ & 2645 & 3721 & 897 & 117 & 16568 & 3471 & $\mathbf{2 7 4 1 9}$ \\
\hline $\begin{array}{l}\text { Dziennik ukazujący się } \\
\text { 3 razy w tygodniu }\end{array}$ & 23354 & 27448 & 5427 & 843 & 112295 & 24849 & $\mathbf{1 9 4 2 1 6}$ \\
\hline $\begin{array}{l}\text { Dziennik ukazujący się } \\
\text { 7 razy w tygodniu }\end{array}$ & 43629 & 44928 & 7434 & 1128 & 160455 & 37172 & $\mathbf{2 9 4} \mathbf{7 4 6}$ \\
\hline Miesięcznik & 3321 & 4291 & 1842 & 3 & 44406 & 5304 & $\mathbf{5 9 1 6 7}$ \\
\hline Trzytygodnik & 684 & 735 & 317 & & 7392 & 1156 & $\mathbf{1 0 2 8 4}$ \\
\hline Tygodnik & 607 & 1061 & 427 & 3 & 9183 & 1475 & $\mathbf{1 2 ~ 7 5 6}$ \\
\hline Suma końcowa & $\mathbf{8 4} \mathbf{6 0 0}$ & $\mathbf{9 4 5 7 6}$ & $\mathbf{1 9 6 9 5}$ & $\mathbf{2 2 6 3}$ & $\mathbf{4 2 9} \mathbf{0 2 2}$ & $\mathbf{8 6} \mathbf{6 0 2}$ & $\mathbf{7 1 6 7 5 8}$ \\
\hline
\end{tabular}

Źródło: Lokalny dystrybutor prasy w powiecie polickim. Opracowanie własne.

Zwroty egzemplarzowe prasy wyniosły odpowiednio dla: dzienników ukazujących się 7 dni w tygodniu 41,12\%, dzienników ukazujących się 3 razy w tygodniu $27,10 \%$, dwutygodników $16,18 \%$, miesięczników $8,25 \%$, dziennik ukazujący się 2 razy w tygodniu 3,83\%, tygodniki 1,78\%, trzytygodniki $1,43 \%$, czasopismo ukazujące się 2 razy w miesiącu $0,19 \%$ i 3 razy w miesiącu $0,12 \%$.

W tabeli 26 wyliczona jest wielkość sprzedaży egzemplarzowej tytułów prasowych według periodyczności. 
Tabela 26

Powiat policki wielkość sprzedaży prasy w egzemplarzach według periodyczności w okresie 10.2008-10.2009

\begin{tabular}{|c|c|c|c|c|c|c|c|}
\hline & $\begin{array}{l}\text { Dobra } \\
\text { (Szcze- } \\
\text { cińska) }\end{array}$ & $\begin{array}{c}\text { Kolbas- } \\
\text { kowo }\end{array}$ & $\begin{array}{c}\text { Nowe } \\
\text { Warpno } \\
\text { miasto }\end{array}$ & $\begin{array}{c}\text { Nowe } \\
\text { Warpno } \\
\text { obszar } \\
\text { wiejski }\end{array}$ & $\begin{array}{c}\text { Police - } \\
\text { miasto }\end{array}$ & $\begin{array}{c}\text { Police - } \\
\text { obszar } \\
\text { wiejski }\end{array}$ & $\begin{array}{c}\text { Suma } \\
\text { końco- } \\
\text { wa }\end{array}$ \\
\hline $\begin{array}{l}\text { Czasopismo ukazujące } \\
\text { się } 2 \text { razy w miesiącu }\end{array}$ & 23 & 62 & 12 & & 305 & 78 & 480 \\
\hline $\begin{array}{l}\text { Czasopismo ukazujące } \\
\text { się } 3 \text { razy w miesiącu }\end{array}$ & 14 & 27 & 25 & & 384 & 50 & 500 \\
\hline Dwutygodnik & 9871 & 17132 & 3206 & 187 & 64202 & 10871 & 105469 \\
\hline $\begin{array}{l}\text { Dziennik ukazujący się } \\
2 \text { razy w tygodniu }\end{array}$ & 4643 & 8478 & 1849 & 66 & 23031 & 5696 & 43763 \\
\hline $\begin{array}{l}\text { Dziennik ukazujący się } \\
3 \text { razy w tygodniu }\end{array}$ & 31445 & 42423 & 10186 & 534 & 157060 & 39006 & 280654 \\
\hline $\begin{array}{l}\text { Dziennik ukazujący się } \\
7 \text { razy w tygodniu }\end{array}$ & 71986 & 76280 & 10678 & 457 & 240650 & 66023 & 466074 \\
\hline Miesięcznik & 2929 & 3929 & 1520 & 11 & 35632 & 4240 & 48261 \\
\hline Trzytygodnik & 588 & 578 & 169 & & 3922 & 629 & 5886 \\
\hline Tygodnik & 274 & 815 & 226 & 9 & 3640 & 582 & 5546 \\
\hline Suma końcowa & 121773 & 149724 & 27871 & 1264 & 528826 & 127175 & 956633 \\
\hline
\end{tabular}

Źródło: Lokalny dystrybutor prasy w powiecie polickim. Opracowanie własne.

Największą sprzedaż egzemplarzową prasy odnotowano dla: dzienników ukazujących się 7 dni w tygodniu 48,72\%, dzienników ukazujących się 3 razy w tygodniu 29,34\%, dwutygodników 11,03\%, miesięczników $5,04 \%$, dziennik ukazujący się 2 razy w tygodniu $4,57 \%$ tygodniki $0,58 \%$, trzytygodniki $0,62 \%$, czasopismo ukazujące się 2 razy w miesiącu $0,05 \%$ i 3 razy w miesiącu $0,05 \%$.

Tabela 27 określa wartość sprzedaży (w PLN) tytułów prasowych według periodyczności.

Wartość sprzedaży prasy opiewa odpowiednio dla: dzienników ukazujących się 7 dni w tygodniu 32,42\%, dzienników ukazujących się 3 razy w tygodniu 24,66\%, dwutygodników 20,01\%, miesięczników 13,08\%, dziennik ukazujący się 2 razy w tygodniu (6,78\%), tygodniki (1,50\%), trzytygodniki $(1,33 \%)$, czasopismo ukazujące się 2 razy w miesiącu $(0,13 \%)$ i 3 razy w miesiącu $(0,09 \%)$.

Tabela 28 precyzuje wartość nakładów (w PLN) tytułów prasowych według periodyczności. 
Powiat policki - wartość sprzedaży prasy (w PLN) według periodyczności w okresie 10.2008-10.2009

\begin{tabular}{|c|c|c|c|c|c|c|c|}
\hline & $\begin{array}{l}\text { Dobra } \\
\text { (Szcze- } \\
\text { cińska) }\end{array}$ & $\begin{array}{c}\text { Kolbas- } \\
\text { kowo }\end{array}$ & $\begin{array}{c}\text { Nowe } \\
\text { Warpno } \\
\text { miasto }\end{array}$ & $\begin{array}{c}\text { Nowe } \\
\text { Warpno } \\
\text { obszar } \\
\text { wiejski }\end{array}$ & $\begin{array}{l}\text { Police - } \\
\text { miasto }\end{array}$ & $\begin{array}{c}\text { Police - } \\
\text { obszar } \\
\text { wiejski }\end{array}$ & $\begin{array}{c}\text { Suma } \\
\text { końcowa }\end{array}$ \\
\hline $\begin{array}{l}\text { Czasopismo ukazujące } \\
\text { się } 2 \text { razy w miesiącu }\end{array}$ & 152 & 350 & 90 & & 2180 & 585 & 3356 \\
\hline $\begin{array}{l}\text { Czasopismo ukazujące } \\
\text { się } 3 \text { razy w miesiącu }\end{array}$ & 92 & 153 & 132 & & 1826 & 287 & 2490 \\
\hline Dwutygodnik & 46435 & 88575 & 15211 & 846 & 330680 & 48400 & 530146 \\
\hline $\begin{array}{l}\text { Dziennik ukazujący się } \\
2 \text { razy w tygodniu }\end{array}$ & 17073 & 31228 & 9707 & 137 & 101276 & 20249 & 179670 \\
\hline $\begin{array}{l}\text { Dziennik ukazujący się } \\
3 \text { razy w tygodniu }\end{array}$ & 74282 & 109388 & 23699 & 1121 & 359580 & 85189 & 653259 \\
\hline $\begin{array}{l}\text { Dziennik ukazujący się } \\
7 \text { razy w tygodniu }\end{array}$ & 132962 & 142358 & 20118 & 770 & 447402 & 115278 & 858888 \\
\hline Miesięcznik & 16679 & 28245 & 12690 & 39 & 261200 & 27537 & 346389 \\
\hline Trzytygodnik & 3090 & 3211 & 1216 & & 24590 & 3191 & 35297 \\
\hline Tygodnik & 1863 & 5330 & 1236 & 26 & 27333 & 3957 & 39745 \\
\hline Suma końcowa & 292627 & 408838 & 84100 & 2938 & 1556067 & 304672 & 2649242 \\
\hline
\end{tabular}

Źródło: Lokalny dystrybutor prasy w powiecie polickim. Opracowanie własne.

Powiat policki - wartość nakładów prasy (w PLN) według periodyczności w okresie 10.2008-10.2009

\begin{tabular}{||l|c|c|c|c|c|c|c||}
\hline \hline & $\begin{array}{c}\text { Dobra } \\
\text { (Szcze- } \\
\text { cińska) }\end{array}$ & $\begin{array}{c}\text { Kołbas- } \\
\text { kowo }\end{array}$ & $\begin{array}{c}\text { Nowe } \\
\text { Warpno } \\
\text { miasto }\end{array}$ & $\begin{array}{c}\text { Nowe } \\
\text { Warpno } \\
\text { obszar } \\
\text { wiejski }\end{array}$ & $\begin{array}{c}\text { Police - } \\
\text { miasto }\end{array}$ & $\begin{array}{c}\text { Police - } \\
\text { obszar } \\
\text { wiejski }\end{array}$ & $\begin{array}{c}\text { Suma } \\
\text { końcowa }\end{array}$ \\
\hline 1 & 2 & 3 & 4 & 5 & 6 & 7 & 8 \\
\hline $\begin{array}{l}\text { Czasopismo ukazujące } \\
\text { się 2 razy w miesiącu }\end{array}$ & 640 & 1151 & 223 & & 9832 & 1932 & $\mathbf{1 3 7 7 9}$ \\
\hline $\begin{array}{l}\text { Czasopismo ukazujące } \\
\text { się 3 razy w miesiącu }\end{array}$ & 281 & 931 & 565 & & 6266 & 964 & $\mathbf{9 0 0 7}$ \\
\hline Dwutygodnik & 99153 & 153307 & 32193 & 1442 & 779728 & 119803 & $\mathbf{1 1 8 5 6 2 7}$ \\
\hline $\begin{array}{l}\text { Dziennik ukazujący się } \\
\text { 2 razy w tygodniu }\end{array}$ & 30111 & 48107 & 14501 & 467 & 197440 & 36572 & $\mathbf{3 2 7} 197$ \\
\hline $\begin{array}{l}\text { Dziennik ukazujący się } \\
\text { 3 razy w tygodniu }\end{array}$ & 142024 & 191213 & 39559 & 3175 & 701391 & 156090 & $\mathbf{1 2 3 3 4 5 1}$ \\
\hline
\end{tabular}




\begin{tabular}{||l|r|r|r|r|r|r|r||}
\hline \multicolumn{1}{|c|}{1} & \multicolumn{1}{c|}{2} & \multicolumn{1}{c|}{3} & \multicolumn{1}{c|}{4} & \multicolumn{1}{c|}{5} & \multicolumn{1}{c|}{6} & \multicolumn{1}{c|}{7} & \multicolumn{1}{c|}{8} \\
\hline $\begin{array}{l}\text { Dziennik ukazujący się } \\
\text { 7 razy w tygodniu }\end{array}$ & 222783 & 234260 & 35509 & 2634 & 775833 & 188910 & $\mathbf{1 4 5 9} 931$ \\
\hline Miesięcznik & 41669 & 63794 & 28475 & 63 & 623859 & 69119 & $\mathbf{8 2 6} \mathbf{9 8 0}$ \\
\hline Trzytygodnik & 8025 & 7849 & 3605 & & 81476 & 11204 & $\mathbf{1 1 2} \mathbf{1 5 9}$ \\
\hline Tygodnik & 6176 & 12709 & 4024 & 35 & 104663 & 16250 & $\mathbf{1 4 3 8 5 7}$ \\
\hline Suma końcowa & $\mathbf{5 5 0} \mathbf{8 6 3}$ & $\mathbf{7 1 3 ~ 3 2 1}$ & $\mathbf{1 5 8} \mathbf{6 5 4}$ & $\mathbf{7 8 1 6}$ & $\mathbf{3 2 8 0 4 8 8}$ & $\mathbf{6 0 0} \mathbf{8 4 5}$ & $\mathbf{5 3 1 1} \mathbf{9 8 8}$ \\
\hline
\end{tabular}

Źródło: Lokalny dystrybutor prasy w powiecie polickim. Opracowanie własne.

Wartość nakładów prasy określa się dla: dzienników ukazujących się 7 dni w tygodniu $27,48 \%$, dzienników ukazujących się 3 razy w tygodniu 23,22\%, dwutygodników 22,32\%, miesięczników 15,57\%, dziennik ukazujący się 2 razy w tygodniu $6,16 \%$, tygodniki $2,71 \%$, trzytygodniki $2,11 \%$, czasopismo ukazujące się 2 razy w miesiącu $0,26 \%$ i 3 razy w miesiącu $0,17 \%$.

W tabeli 29 znajduje się informacja o wartości zwrotów (w PLN) tytułów prasowych według periodyczności.

Tabela 29

Powiat policki - wartość zwrotów (w PLN) według periodyczności w okresie 10.2008-10.2009

\begin{tabular}{|c|c|c|c|c|c|c|c|}
\hline & $\begin{array}{c}\text { Dobra } \\
\text { (Szcze- } \\
\text { cińska) }\end{array}$ & $\begin{array}{l}\text { Kolbas- } \\
\text { kowo }\end{array}$ & $\begin{array}{c}\text { Nowe } \\
\text { Warpno } \\
\text { miasto }\end{array}$ & $\begin{array}{c}\text { Nowe } \\
\text { Warpno } \\
\text { obszar } \\
\text { wiejski }\end{array}$ & $\begin{array}{c}\text { Police - } \\
\text { miasto }\end{array}$ & $\begin{array}{c}\text { Police - } \\
\text { obszar } \\
\text { wiejski }\end{array}$ & $\begin{array}{c}\text { Suma } \\
\text { końcowa }\end{array}$ \\
\hline $\begin{array}{l}\text { Czasopismo ukazujące } \\
\text { się } 2 \text { razy w miesiącu }\end{array}$ & 488 & 801 & 133 & & 7653 & 1347 & 10423 \\
\hline $\begin{array}{l}\text { Czasopismo ukazujące } \\
\text { się } 3 \text { razy w miesiącu }\end{array}$ & 189 & 778 & 432 & & 4440 & 677 & 6517 \\
\hline Dwutygodnik & 52718 & 64732 & 16982 & 596 & 449049 & 71404 & 655481 \\
\hline $\begin{array}{l}\text { Dziennik ukazujący się } \\
2 \text { razy w tygodniu }\end{array}$ & 13038 & 16879 & 4793 & 330 & 96164 & 16323 & 147527 \\
\hline $\begin{array}{l}\text { Dziennik ukazujący się } \\
3 \text { razy w tygodniu }\end{array}$ & 67742 & 81824 & 15860 & 2054 & 341811 & 70901 & 580192 \\
\hline $\begin{array}{l}\text { Dziennik ukazujący się } \\
7 \text { razy w tygodniu }\end{array}$ & 89821 & 91902 & 15391 & 1865 & 328431 & 73633 & 601043 \\
\hline Miesięcznik & 24990 & 35550 & 15786 & 24 & 362659 & 41582 & 480591 \\
\hline Trzytygodnik & 4935 & 4638 & 2389 & & 56885 & 8014 & 76861 \\
\hline Tygodnik & 4313 & 7379 & 2788 & 9 & 77330 & 12293 & 104112 \\
\hline Suma końcowa & 258236 & 304483 & 74554 & 4877 & 1724422 & 296174 & 2662746 \\
\hline
\end{tabular}

Źródło: Lokalny dystrybutor prasy w powiecie polickim. Opracowanie własne. 
Natomiast wartość zwrotów prasy kształtuje się dla: dzienników ukazujących się 7 dni w tygodniu 22,57\%, dzienników ukazujących się 3 razy w tygodniu $21,79 \%$, dwutygodników 24,62\%, miesięczników 18,05\%, dziennik ukazujący się 2 razy w tygodniu 5,54\%, tygodniki 3,91\%, trzytygodniki $2,89 \%$, czasopismo ukazujące się 2 razy w miesiącu $0,39 \%$ i 3 razy w miesiącu $0,24 \%$.

Jak wykazały badania ilościowe danych udostępnionych przez jednego z lokalnych dystrybutorów prasy, jak również analiza ankiet i badań jakościowych prasy lokalnej w powiecie polickim, rynek prasowy koncentruje się głównie na terenie gminy Police. Tam jest zlokalizowanych najwięcej punktów sprzedaży detalicznej prasy, do których są kierowane największe nakłady. Gmina Police generuje największą sprzedaż egzemplarzową, a co za tym idzie największą wartość sprzedaży prasy. W gminie Police jest wydawana i rozpowszechniania też w zdecydowanej większości prasa lokalna.

\section{Podsumowanie}

Niniejszy artykuł ma na celu zaprezentowanie próbki prowadzonych przeze mnie badań nad prasą lokalną w województwie zachodniopomorskim. Ich podstawą jest analiza rynku lokalnego prasy w powiecie polickim. Na pierwszy rzut oka widać, jaki ogrom informacji i wiedzy dostarcza penetracja rynku lokalnego. Szeroko możemy porównywać lub też korelować dane zawarte w organach rejestrowych, dostępne w Internecie, bazach adresowych, z danymi, które udostępniają nam sami wydawcy lub też korzystając z uprzejmości lokalnych dystrybutorów prasy.

Wybrane tytuły prasowe powiatu polickiego stanowią przede wszystkim głos społeczności lokalnej. Niejednokrotnie osoby wydające tytuł lokalny współpracują z samorządem lokalnym lub też z komitetami i organami partii politycznych lub lokalnych stowarzyszeń. To właśnie z prasy lokalnej możemy się dowiedzieć bardzo szczegółowo o codziennym życiu i funkcjonowaniu lokalnej społeczności. Ta różnorodność oscyluje od informacji samorządowych, parafialnych, po biznesowe i reklamowe. Próżno szukać informacji o lokalnej działalności gospodarczej w tytułach ogólnokrajowych czy nawet regionalnych. O przysłowiowym zakładzie fryzjerskim Pani Zosi przeczytamy tylko w prasie lokalnej, ogłoszeń parafialnych nie znajdziemy w wysokonakładowych pismach. To właśnie jest urok prasy lokalnej. Prasa lokalna w większości uzależniona jest od jedne- 
go właściciela. Ważne są jego zdolności, znajomości i umiejętności poruszania się w społeczności lokalnej.

Poruszane w niniejszym artykule kwestie są zalążkiem prowadzonych obserwacji i rozważań.

\section{Summary}

The paper presents partial results of the research into the local press the author has carried out in the Western Pomeranian province. A detailed analysis concerns the titles published in the territorial units at a district level. There are 18 of those, including three towns with district status, in the Western Pomeranian province. The results presented are based on extensive qualitative and quantitative surveys. The diversification of the local press, its abundance, development and end are inseparably related to local entrepreneurship and the communication process in local communities.

The paper comprises three parts. The first one explains the terminology of the press and press market. The second one characterizes the local community of the Police district. The third one discusses the results of qualitative surveys and presents the quantitative analysis of local press circulation. 